University of Louisville

ThinkIR: The University of Louisville's Institutional Repository

\title{
The electoral victory of John Bell and the constitutional Union in Kentucky, 1860.
}

Samuel Thomas Whittaker

University of Louisville

Follow this and additional works at: https://ir.library.louisville.edu/honors

Part of the United States History Commons

\section{Recommended Citation}

Whittaker, Samuel Thomas, "The electoral victory of John Bell and the constitutional Union in Kentucky, 1860." (2015). College of Arts \& Sciences Senior Honors Theses. Paper 29.

http://doi.org/10.18297/honors/29

This Senior Honors Thesis is brought to you for free and open access by the College of Arts \& Sciences at ThinkIR: The University of Louisville's Institutional Repository. It has been accepted for inclusion in College of Arts \& Sciences Senior Honors Theses by an authorized administrator of ThinkIR: The University of Louisville's Institutional Repository. This title appears here courtesy of the author, who has retained all other copyrights. For more information, please contact thinkir@louisville.edu. 
The Electoral Victory of John Bell and the Constitutional Union in Kentucky, 1860 By

Samuel Thomas Whittaker

Submitted in partial fulfillment of the requirements for graduation Summa Cum Laude

and

for Graduation with Honors from the Department of History

University of Louisville

March 2015 


\section{$\underline{\text { Table of Contents }}$}

Introduction and Historiography: Pages 2-9

Chapter 1: The Backdrop of the Campaign: Pages 9-39

Chapter 2: The Conduct of the Campaign in Kentucky: Pages 39-58

Chapter 3: Analysis of the Results and Border State Comparison: Pages 59-66 


\section{$\underline{\text { Introduction }}$}

The presidential election of 1860 is one of the most studied in United States history. Four candidates contested the presidential race that saw the Democratic Party split in two and the Republican Party gain the presidency without a single southern electoral vote. The election precipitated the Civil War as the victory of Abraham Lincoln and the Republicans led to the secession of southern states from the Union. A wealth of historians have focused on the role of Lincoln and the rise of the Republican Party in the election. Many have also examined the Democratic split as northern Democrats backed Illinois Senator Stephen Douglas and southern Democrats gave their support to Vice President John C. Breckenridge of Kentucky. However, relatively few historians have made Tennessee Senator and Constitutional Union presidential candidate John Bell the focus of their work, despite the fact that he received 39 electoral votes and carried Virginia, Kentucky, and Tennessee, all located within the key border region between the North and Deep South.

Bell failed to secure the national support necessary to become president of the United States. However, his pluralities in three key states and strong showings in the Upper South/Border States of Maryland, Missouri, and North Carolina merit further study. Bell's electoral success in Kentucky may be attributed to three key factors. First, as the Constitutional Union candidate, Bell received the support of influential former Whig Party politicians from Kentucky such as Senator John J. Crittenden, former Congressman Garret Davis, and former Governor Charles S. Morehead. Bell gained the loyalty of former Whig voters in Kentucky which had been a stronghold of the party and home to its greatest leader, Henry Clay. The Whig tradition in Kentucky gave Bell a firm support system in the state. Second, Bell enjoyed the advantage of a divided Democratic Party. Though John C. Breckenridge had the support of a 
majority of Kentucky Democrats, Stephen Douglas peeled away a crucial twenty-five thousand Democratic votes to open the door for Bell's victory. The divided Kentucky Democracy significantly weakened Bell's opposition. Finally, the Constitutional Union Party of Kentucky ran a successful campaign with an appealing message to Kentucky voters. The Constitutional Union rhetoric in the state emphasized popular pro-Union and proslavery positions successfully. This pro-Union and proslavery message earned the trust and support of Kentucky voters, ultimately granting Bell an electoral victory in the state. A unique political situation existed in each border state, but these three factors to Bell's success, though varying in importance, played a role throughout the states where Bell had significant electoral support.

\section{Historiography}

Historians have usually viewed the Constitutional Union Party in the 1860 election through the lens of another candidate. For example, Daniel Egerton's Year of Meteors focuses primarily on the Lincoln and Douglas campaigns. ${ }^{1}$ His chapter dealing with the Constitutional Union Party also discusses the abolitionist Liberty Party which received only a smattering of voters and proved largely irrelevant. Allan Nevins's multi-volume work, The Emergence of Lincoln likewise deals with the Constitutional Union Party primarily in a single section. ${ }^{2}$ In contrast, the Constitutional Union has been the focal point of some scholarship. For example, John V. Mering's article, “The Slave State Constitutional Unionists and the Politics of Consensus," in The Journal of Southern History, focuses on the role of the Constitutional Union Party in the

\footnotetext{
${ }^{1}$ Daniel Egerton, Year of Meteors: Stephen Douglas, Abraham Lincoln and the Election That Brought on the Civil War (New York, NY: Bloomsbury Publishing, 2010).

${ }^{2}$ Allan Nevins, The Emergence of Lincoln, Volume II, (New York, NY: Charles Scribner and Sons, 1950).
} 
South. ${ }^{3}$ This paper views the election of 1860 in Kentucky through the lens of the Constitutional Union Party, thereby filling in a gap in the historiography by granting the party the main focus.

Much scholarship on the 1860 election minimizes the appeal of Bell's candidacy and the Constitutional Union platform. Bell's biographer, Joseph Howard Parks, deems Bell an unexciting candidate and perhaps an unwise choice. ${ }^{4}$ Albert D. Kirwan, the biographer of Crittenden, describes Bell as "overweight, not very exciting, and lacking popular support." historians have labeled Bell an outdated statesman leading an outdated party. They, like many contemporary politicians, have deemed the Constitutional Union platform as useless because it said nothing, remaining opportunistically silent on the issue of slavery, the primary political issue of the day. For example, historian E.D. Fite, in The Election of 1860, described the Constitutional Union platform as "two-faced" and Bell as falling on every side of the slavery issue. ${ }^{6}$ However, Bell proved a fitting choice as the candidate for the Constitutional Union as their composition and goals called for an elder statesman from the conservative Whig tradition. Moreover, Bell had the ability to gain the support of voters, especially in Border States such as Kentucky. The Constitutional Union platform, rather than deliberately two-faced, sought to take slavery out of the national discussion which, in itself, constituted a policy outcome and plan. The Constitutional Union in Kentucky embraced a clear message of protection of the institution of slavery, and Bell's record on slavery was conservative, pragmatic, and protectionist.

Historians who study antebellum politics prior to the Civil War have documented the Whig tradition and support for the Constitutional Union. Scholars such as James Fuller (The

\footnotetext{
3 John V. Mering, "The Slave-State Constitutional Unionists and the Politics of Consensus," The Journal of Southern History 43 (1977): 395-410.

${ }^{4}$ Joseph Howard Parks, John Bell of Tennessee (Baton Rouge, LA: Louisiana State University Press, 1950).

${ }^{5}$ Albert D. Kirwan, John J Crittenden: The Struggle for Union (Lexington, KY: University of Kentucky Press, 1962).

${ }^{6}$ E.D. Fite, The Election of 1860 (New York, NY: The MacMillan Company, 1960).
} 
Election of 1860 Reconsidered), Daniel Egerton, and John Ashworth have all viewed the Constitutional Union as the inheritor of the Whig mantle and a revival of traditional Whig politics. ${ }^{7}$ The support of former Whigs gave Bell a ready base of political support in Kentucky and served as his first step to victory in the state in 1860. Many good histories of the Whig Party including Michael F. Holt's Rise and Fall of the American Whig Party and Arthur Charles Cole's Whig Party in the South, track the movement of former Whigs in the 1850s into the American Party, then the Opposition, and later to the Constitutional Union. ${ }^{8}$

The election of 1860 in Kentucky has been studied in several different works. In The Slave States in the Presidential Election of 1860, Ollinger Crenshaw provided a survey of the election in Kentucky. He discussed the diversity of opinion in the commonwealth, the importance of pro-Union politics in the election, and the benefits Bell received from the Douglas campaign. As part of a larger work, he does not delve into extensive detail about all facets of the election, but he covered most of the highpoints including the interesting fight over Henry Clay's legacy. ${ }^{9}$ In his Ph.D. dissertation, "Kentucky Will Be the Last to give up the Union," Christopher Paine treats the politics of the late 1850s in a chapter. Paine correctly demonstrates the continuing importance of the Whig legacy in Kentucky along with prominent politicians like Crittenden. Paine uses the election to demonstrate Kentucky's persistent attachment to the Union. He argues that the pro-Union rhetoric of the Breckenridge, Douglas, and Bell campaigns

\footnotetext{
${ }^{7}$ A. James Fuller, The Election of 1860 Reconsidered (Kent, Ohio: Kent State University Press, 2013). John Ashworth, Slavery, Capitalism, and Politics in the Antebellum Republic: The Coming of the Civil War, Volume II (Cambridge, United Kingdom: Cambridge University Press, 2007).

${ }^{8}$ Michael F. Holt, The Rise and Fall of the American Whig Party: Jacksonian Politics and the Onset of the Civil War (New York, NY: Oxford University Press, 1999). Arthur Charles Cole, The Whig Party in the South (Gloucester, MA: The American Historical Association, 1962).

${ }^{9}$ Ollinger Crenshaw, The Slave States in the Presidential Election of 1860, (Baltimore, MD: Johns Hopkins University Press, 1969).
} 
in Kentucky indicates the importance of Union issues in Kentucky in $1860 .{ }^{10}$ But both Crenshaw and Paine fail to place enough emphasis on the decidedly proslavery tone of both the Bell and Breckenridge campaigns in Kentucky. While they correctly link the interests of Union and slavery, both fail to delve into slave politics in the election. The argument of this thesis most closely mirrors the work of John V. Mering on slave-state Constitutional Unionists, and it narrows the emphasis to a single state in order to paint a specific portrait.

The politics of slavery proved a key issue in the 1860 election in Kentucky, indicating the significance of the institution in the state. Scholars such as John W. Coleman, Marion Lucas, and Harold Tallant have provided useful studies of Kentucky slavery. Coleman's Slavery Times in Kentucky, completed in 1940, offered an in-depth look at slavery in Kentucky including plantation life, the slave trade, runaways, Kentucky dissenters, and the violence that sustained the institution. Coleman argued that in Kentucky "the yoke of bondage rested lightly" compared to the slave states of the Deep South. Coleman's portrait of Kentucky slavery as more mild than elsewhere in the U.S. persists to this day. Despite his dated racial language and claims for the relative mildness of Kentucky slavery, Coleman still occasionally recognized the "cruel and brutal" characteristics of the institution. ${ }^{11}$ Marion Lucas, in A History of Blacks in Kentucky, expands on the work of Coleman. While emphasizing the inherent force and violence behind slavery in Kentucky and offering a more accurate depiction than Coleman, Lucas cannot resist the conclusion that slavery in Kentucky proved milder than in the Deep South. ${ }^{12}$

\footnotetext{
${ }^{10}$ Christopher M. Paine, "Kentucky Will be the Last to give up the Union" (Ph.D. Dissertation, University of Kentucky 1998).

${ }^{11} \mathrm{~J}$. Winston Coleman, Slavery Times in Kentucky (Chapel Hill, NC: University of North Carolina Press, 1940).

${ }_{12}$ Marion Lucas, A History of Blacks in Kentucky: From Slavery to Segregation, 1790-1891 (Frankfort, KY: Kentucky Historical Society, 1992), 50.
} 
In Evil Necessity: Slavery and Political Culture in Antebellum Kentucky, Harold Tallant likewise differentiates Kentucky from other slave societies. Focusing on the antislavery sentiments expressed by prominent Kentucky politicians such as Henry Clay, the presence of a politically active antislavery community in Kentucky, and the relative moderation of slavery's defense, he argues that Kentuckians saw slavery as a "necessary evil" rather than a positive good, like Deep South residents. ${ }^{13}$ James Ramage and Andrea S. Watkins's recent study of antebellum Kentucky politics, Kentucky Rising: Democracy, Slavery, and Culture from the Early Republic to the Civil War, draws on Tallant's work to argue that Kentucky exhibited a relative diversity of opinion about slavery. However, the both works also note the protections afforded slavery by Kentucky politicians, the updated state constitutions, and increasingly stringent slave laws, thereby demonstrating the commitment of white Kentuckians to protect the institution. ${ }^{14}$ Historian Lowell Harrison offered a detailed history of the antislavery movement discussed by Ramage and Watkins, Lucas, and Tallant in The Antislavery Movement in Kentucky. ${ }^{15}$

In 1860 , the population of Kentucky amounted to $1,155,684$ individuals, making it the ninth largest state in the Union and the third largest slave state. ${ }^{16}$ Kentuckians owned 225,483 slaves, accounting for 19 percent of the population and placing it ninth in terms of slave population of the fifteen slaveholding states. Nonetheless, 38,645 slave owners resided in the commonwealth, giving Kentucky the third largest number of owners behind only Virginia and Georgia. ${ }^{17}$ The state's large enslaved and slaveholding populations afforded the peculiar

\footnotetext{
${ }^{13}$ Harold D. Tallant, Evil Necessity: Slavery and Political Culture in Antebellum Kentucky (Lexington, KY: University of Kentucky Press).

${ }^{14}$ James Ramage and Andrea S. Watkins, Kentucky Rising: Democracy, Slavery, and Culture from the Early Republic to the Civil War (Lexington, KY: University of Kentucky Press, 2011).

${ }^{15}$ Lowell Harrison, The Antislavery Movement in Kentucky (Lexington, KY: University of Kentucky Press, 1978).

${ }^{16}$ Kenneth H. Williams and James Russell Harris, "Kentucky in 1860: A Statistical Overview," Register of the Kentucky Historical Society 103 (2005): 751.

${ }^{17} \mathrm{lbid}$.
} 
institution political, economic, and social importance. In the election of 1860, voters with an interest in slavery sought protection for the institution. Constitutional Union Party success depended partially on appealing to these voters.

The party's strategy in 1860 followed the long standing dynamic of slave politics in Kentucky. Over time, slave codes and regulations on free blacks became more stringent. In 1799, the Kentucky Constitution banned free blacks from owning guns and removed the right of suffrage from free blacks. ${ }^{18}$ When the Kentucky legislature called a convention to amend the state constitution in 1850, antislavery Kentuckians hoped they might increase the rights of free blacks and even embark on a path to gradual abolition. ${ }^{19}$ However, when white male Kentuckians went to the polls, they elected an overwhelmingly proslavery convention. The 1850 Constitution represented the most comprehensive protection of slaveholders' rights in Kentucky history. ${ }^{20}$ Clearly, the majority of white Kentuckians, whether or not they viewed slavery as a necessary evil, wanted to protect the institution.

According to Ramage and Watkins, white Kentuckians desired the protection of slavery for four reasons. First, they believed in the racial inferiority of African Americans and thought free blacks posed a threat to public safety through theft or violence. ${ }^{21}$ Black freedom, white voters concluded, would result in race war, racial mixing, and social disorder. Second, white Kentuckians supported the property rights of slave owners and felt loyalty to the slave South. ${ }^{22}$ Third, agricultural slavery and the slave trade benefitted the Kentucky economy. Lexington and Louisville had large slave markets and the Ohio River connection to the Mississippi enabled easy

\footnotetext{
${ }^{18}$ Ramage and Watkins, Kentucky Rising, 260.

19 Tallant, Evil Necessity, 137-9.

20 Ibid., 151-3.

${ }^{21}$ Ramage and Watkins, Kentucky Rising, 272-3.

22 Ibid., 259.
} 
transportation of Kentucky slaves to the Deep South. ${ }^{23}$ Finally, most white Kentuckians believed that the Union and the Constitution, at minimum, protected the institution of slavery where it presently existed.

Despite constitutional and legal statutes protecting the institution of slavery and oppressing the free black population, a small yet vocal minority of Kentuckians opposed slavery in the commonwealth, representing the largest antislavery white population in the South. ${ }^{24}$ The Kentucky branch of the American Colonization Society, dedicated to the removal of blacks to Liberia after gradual manumission, had the third largest number of chapters of any state in the Union. ${ }^{25}$ More radical voices, including Whig politician Cassius Clay and minister John Fee, sought a more immediate end to slavery. With the help of Clay, Fee organized the "Bereans," an abolitionist organization that founded a school to provide education to Kentucky's free black population and used moral suasion to end slavery in Kentucky. ${ }^{26}$ Despite such voices, the majority of white Kentuckians supported the institution of slavery and sought its protection. As a result, any candidate hoping to carry the state in 1860 had to assure voters of their commitment to the institution.

\section{Chapter 1: The Backdrop of the Campaign}

\section{The Collapse of the Whig Party and the Politics of the 1850s:}

Assessing the Constitutional Union candidacy of John Bell requires understanding the politics of the 1850s that brought about the demise of the Whig Party, the end of the second party system,

\footnotetext{
${ }^{23} \mathrm{Ibid}$.

${ }^{24}$ Ibid., 257.

${ }^{25} \mathrm{Ibid}$., 260.

${ }^{26}$ Ibid., 268-74.
} 
and the dispersal of Whig voters and politicians into new political organizations. Conservative Whig politicians and their supporters, located primarily in the Border States, became the backbone of the Constitutional Union Party in 1860. After the breakup of the Whig Party, most future Constitutional Union supporters moved into the American Party, then formed the Opposition, and finally joined the Constitutional Union Party. Former Whig political leaders from Kentucky such as John J. Crittenden, Garrett Davis, and Charles S. Morehead, along with their allied newspapers and voters, supported John Bell and the Constitutional Union, giving it a firm electoral base in Kentucky. This base of voters, centered in greater Louisville, Lexington, and the inner Bluegrass region, provided Bell with the first ingredient to his success in 1860.

The politics of compromise and national Union associated with Whig Party leaders such as Daniel Webster and Henry Clay had success, albeit briefly, at the beginning of the decade with the Compromise of 1850 that included concessions to both the North and the South on slavery. It granted the North the admission of California as a free state and banned the slave trade in Washington D.C. The compromise prevented the adoption of the Wilmot Proviso, intended to ban the extension of slavery to new territories, and put in place a more stringent fugitive slave law to appease the South. The compromise, engineered by Henry Clay but passed by breaking the bill into pieces by Illinois Democratic Senator Stephen A. Douglas, enjoyed the support of conservative Border South Whigs such as then Senator Bell and Crittenden who would become the future leaders of the Constitutional Union Party. ${ }^{27}$ In the election of 1860 , the party's campaign literature and allied newspapers praised the compromise of 1850 and claimed it as a success. $^{28}$

\footnotetext{
${ }^{27}$ Parks, John Bell, 265-6.

${ }^{28}$ Louisville Weekly Courier, August 15, 1860.
} 
Conservative Whigs hoped that the Compromise of 1850 would ease sectional tensions and finally settle the slavery question. Crittenden, attorney general in Millard Fillmore's administration, called the compromise "the only salvation for the Union.. ${ }^{29}$ Bell, though a supporter of the compromise, did not share Crittenden's optimism. He believed that the compromise alone would not heal the sectional divide between the North and the South over slavery. ${ }^{30}$ In response to the growing sectional divide within the Whig Party, Bell and other conservative Whigs began to test the waters on the subject of a conservative national union party. ${ }^{31}$ The initial plans for such a party included the unification of moderate Whigs and Democrats behind a platform dedicated to supporting of the Compromise of 1850 and combating sectional agitation. By encouraging compromise, this party could protect both slavery and the Union. ${ }^{32}$ Alexander Stephens and Robert Toombs, both of Georgia, led the charge to create the new party. Ultimately, Bell did not sign the document circulated among national legislators in 1850 supporting the formation of such a party because his political advisors in Tennessee encouraged reform of and loyalty to the existing Whig Party. This early effort to forge a national union party foreshadowed the creation of the Constitutional Union Party in 1860. Six United States congressmen from Kentucky signed the document of support along with the state's senior senator and statesman, Henry Clay. ${ }^{33}$ Kentucky political leaders' support of a national union party designed to calm sectional agitation and protect slavery and the union in 1850 , foreshadowed the state's support of the Constitutional Union Party in 1860.

\footnotetext{
${ }^{29}$ Kirwan, John J. Crittenden and the Struggle for Union, 269.

${ }^{30}$ Parks, John Bell of Tennessee, 265-66.

$31 \mathrm{lbid}$.

${ }^{32}$ Michael F. Holt, The Rise and Fall of the American Whig Party, (Oxford, UK: Oxford University Press, 2003), 617621.

${ }^{33} \mathrm{lbid}$.
} 
The Whig Party came out of the Compromise of 1850 intact, but with a growing divide between northern antislavery and southern proslavery Whigs. Before the Whig nominating convention of 1852, southern Whigs supported President Millard Fillmore and the Compromise of 1850. In contrast, northern Whigs thought Fillmore and the 1850 Compromise too prosouthern. The two sides agreed on General Winfield Scott of Mexican War fame as a compromise candidate. ${ }^{34}$ William A. Graham, a former senator and governor of North Carolina, ran as Scott's vice president. Graham would strongly support the Constitutional Union Party in 1860. In the election of 1852, the Democratic candidate, Franklin Pierce, won in an electoral college landslide, defeating Scott and the Whigs by 254 to $42 .{ }^{35}$ The Whig Party failed to run another presidential candidate after 1852, but Scott and the Whigs carried the Border South strongholds of Kentucky and Tennessee in their party's last election. John Bell and the Constitutional Union would carry both states in 1860, demonstrating the continuity of voter support between the Whigs and the future Constitutional Union Party. ${ }^{36}$ In 1860 , General Scott also gave the Constitutional Union his support. ${ }^{37}$

The debate over the extension of slavery triggered the collapse of the Whig Party. The Compromise of 1850 offered only a brief respite from sectional conflict over slavery, and the nail in the Whig Party coffin was the Kanas-Nebraska Act of $1854 .^{38}$ The act, engineered by Stephen A. Douglas, established the principle of popular sovereignty for determining the extension of slavery into the territories. Popular sovereignty, which became synonymous with Douglas, stated that the residents of a particular territory had the right to decide whether their

\footnotetext{
34 John S.D. Eisenhower, Agent of Destiny: The Life and Times of General Winfield Scott (New York, NY: the Free Press, 1997), 326-7.

35 “1852 Presidential Election,” http://www.270towin.com/1852 Election/, accessed 1/20/2015.

36 Ibid.

${ }^{37}$ Louisville Journal, May 15, 1860.

${ }^{38}$ Holt, The Rise and Fall of the American Whig Party, 836.
} 
territory would allow or prohibit the extension of slavery. The act organized the territories of Kansas and Nebraska and opened them to the possibility of the extension of slavery on the basis of popular sovereignty. This effectively repealed Henry Clay's hallmark achievement, the 1820 Missouri Compromise, which admitted Missouri to the Union as a slave state, Maine as a free state, and banned extension of slavery north of the $36^{\circ} 30^{\prime}$ latitude line. Kentucky Whig Senator Archibald Dixon authored the amendment that repealed the Missouri Compromise line. ${ }^{39}$ John Bell, serving in the Senate Committee on Territories, allowed the amendment to pass committee, but reserved (and exercised) the right to vote against the act and the amendment because he opposed the repeal of the Missouri Compromise. ${ }^{40}$

The Democratic Party, in control of Congress and with the support of the Pierce administration, pushed the Kansas-Nebraska Act through both the House and the Senate. Most southern Whigs supported the measure, believing the Missouri Compromise line unfairly limited the extension of slavery. Their northern counterparts, however largely opposed the extension of slavery, and most voted against Kansas Nebraska. ${ }^{41}$ After the vote, many southern Whigs renounced their party membership because of the both real and perceived antislavery sentiments of their northern counterparts. ${ }^{42}$ Many northern Whigs, including Abraham Lincoln, ultimately joined the Republican Party, while many Deep South Whigs followed men like Senator Robert Toombs of Georgia who had become a Democrat. ${ }^{43}$ The collapse of the Whig Party left Border South Whigs such as Bell and Crittenden in an awkward position, opposed to antislavery northerners but with no desire to join southern Democrats. ${ }^{44}$ Still, former members of the now

\footnotetext{
${ }^{39}$ Parks, John Bell of Tennesse, 284-5.

40 Ibid.

${ }^{41}$ Holt, Rise and Fall of the American Whig Party, 831.

42 Ibid, 838.

${ }^{43}$ Kirwan, John J. Crittenden, 291.

44 Ibid.
} 
defunct Whig Party remained politically active and looked for new homes while retaining many of their key Whig principles. ${ }^{45}$ In the years to come, many conservative Whigs embraced the nativist Know-Nothing and its political offshoot, the American Party. They later formed the Constitutional Union Party.

Bell and Texas Senator Sam Houston gained the distinction of being the only two senators from slaveholding states to vote against the Kansas-Nebraska Act. ${ }^{46}$ These two men would became the primary candidates for the presidential nomination of the Constitutional Union in 1860 at its Baltimore convention. Bell's opposition to Kansas-Nebraska came from his pragmatic support of the Missouri Compromise, his desire to discourage sectional agitation, and his opposition to further expansion into Native American territories. ${ }^{47}$ Moreover, though he believed Congress had the power to legislate slaveholding in the territories, he also knew that repealing the Missouri Compromise would cause unnecessary sectional conflict. He did not believe slavery could survive in the climate and soil of Kansas or Nebraska, and thus viewed the extension issue an unnecessary abstraction that caused pointless conflict. ${ }^{48}$ As Bell stated in the Senate:

"What has the South to gain by this measure? Will slavery be established under its provisions? Does anyone who has fully considered the subject believe that this territory will become a slave state?"49

\footnotetext{
${ }^{45}$ Holt, Rise and Fall of the American Whig Party, 839.

${ }^{46}$ Parks, John Bell of Tennessee, 285-9.

${ }^{47}$ Ibid., 283.

${ }^{48}$ Ibid., 289-92.

49 "John Bell on the Repeal of the Missouri Compromise," Louisville Weekly Journal, August 29, 1860.
} 
Bell's vote on the Kansas-Nebraska Act would become a topic of discussion in Kentucky during the 1860 campaign. On October 27, the Louisville Courier, an important Kentucky Breckenridge organ, highlighted Bell's Kansas-Nebraska vote to cast doubts on his proslavery credentials. Referring to Bell's vote, the Courier stated, "I do not charge Mr. Bell with being hostile to the institution of slavery. I simply state the facts and leave the people to judge this public act (vote against Kansas-Nebraska). ${ }^{, 50}$ The Louisville Journal, the primary Bell organ in Kentucky, defended Bell's vote and the Missouri Compromise. On May 11, 1860, the Journal described the Kansas-Nebraska Act and its repeal of the Missouri Compromise as "fatally deluded." ${ }^{51}$ On July 25, the Journal, in the form of a letter from Kentucky politician and former U.S. Congressman Garrett Davis, attacked the Democrats and specifically Stephen Douglas for Kansas-Nebraska and the repeal of the Missouri Compromise. ${ }^{52}$ The Journal unequivocally blamed the Democratic Party for the Kansas-Nebraska Act, and the subsequent sectional strife and violence between pro and antislavery forces there on the Democratic Party. The Bell organ hammered home the position that Kansas-Nebraska caused unnecessary sectional strife and emphasized Bell's proslavery pronouncements and record and his personal ownership of slaves. $^{53}$

In 1854, after the collapse of the Whig Party over Kansas-Nebraska and the slavery question, former Whigs, both North and South, began the search for a new political entity. At the same time, the nativist Know-Nothing organization grew in membership and influence. ${ }^{54}$ The Know-Nothings professed an anti-Catholic and anti-immigrant creed. The movement primarily

\footnotetext{
50 “Mr. Bell's Record," Louisville Weekly Courier, October 27, 1860.

51 Louisville Weekly Journal, May 11, 1860, 2.

52 "Letter of Honorable Garrett Davis," Louisville Weekly Journal," July 25, 1860.

${ }^{53}$ Louisville Weekly Journal, August 15, 1860, 2.

54 Holt, The Rise and Fall of the American Whig Party, 837.
} 
began in urban areas that had seen a large influx of Catholic immigrants, but by 1854 , KnowNothing lodges had cropped up throughout the nation from New England to the Deep South states of Louisiana and Alabama. ${ }^{55}$ Though Know-Nothings numbered both Democrats and former Whigs among their ranks and professed to favor neither party, they generally opposed Democratic candidates because of the party's aggressive pursuit of foreign voters and most often endorsed veteran Whig candidates ${ }^{56}$ The Know-Nothing movement thus became the home for conservative Whig opposition to the Democracy. Still, the new organization was not monolithic. Many Democrats also joined Know-Nothing lodges in 1854-55, and the society did endorse some Democratic candidates. ${ }^{57}$

The Know-Nothings, a secret lodge-based society, was not a political party, but the organization gave rise to the American Party, which contested the 1856 elections. After the collapse of the Whig Party in 1854, many Kentucky Whigs initially maintained their independence from the growing Know-Nothing movement. They wanted to avoid the nativists' anti-Catholic message, and maintain their Whig identity as the party that had produced the Great Compromiser Henry Clay. However, the collapse of the national party made this position untenable, Kentucky Whigs went over to the Know-Nothing movement in droves, believing that they could turn it into a national, pro-union party. ${ }^{58}$ John J. Crittenden, one of these somewhat reluctant Kentucky Whigs, supported the American Party, though he did not become a KnowNothing himself. "The great and paramount object of this party," he stated, "should be the maintenance of the Constitution and the Union.. ${ }^{59}$ Likewise, Bell hesitated to embrace Know-

\footnotetext{
$55 \mathrm{Ibid}, 846$.

${ }^{56}$ Ibid., $847-8$

${ }^{57}$ Ibid., 856.

58 Ibid., 935-6

${ }^{59}$ Kirwan, John J. Crittenden.
} 
Nothingism and did not formally join the society. However, in a speech in Knoxville, he called on the American Party, after the demise of the Whig organization, to become a permanent opposition to the Democrats. ${ }^{60}$

The Know-Nothings and Americans did not become the national union party in opposition to Democrats that conservative Whigs like Bell and Crittenden hoped. In the North, antislavery men opposed to the extension of slavery had begun to join the Know-Nothings as they banded together with Republicans in the North. ${ }^{61}$ As early as 1855 , the Know-Nothing movement began to splinter as the Whigs had, and the nation would, along sectional lines. When the Know-Nothings convened in 1855 in Philadelphia, they adopted a resolution not to agitate over slavery, implicitly allowing the Kansas-Nebraska Act to stand. Though this pleased men like Crittenden who hoped to form a new national union party, it prompted most northern KnowNothings to throw their support to the Republican Party. ${ }^{62}$ The American Party ultimately nominated former Whig President Millard Fillmore despite discussion of the nomination going to Bell, Edward Everett, or Garrett Davis. ${ }^{63}$

In 1856, a three way race between the Republican Party (in its first presidential election), the Democratic Party, and the American Party ended with the victory of James Buchanan, the Democratic candidate. Buchanan won 174 electoral votes, carrying the entire South and every border state except Maryland. Fillmore ran strongest in the Border South, as the Constitutional Union would in 1860, but carried only Maryland..$^{64}$ Despite the support of conservative Border State Whigs such as Crittenden, who stumped for Fillmore in the Border South, the nativist

\footnotetext{
${ }^{60}$ Cole, The Whig Party in the South, 321.

${ }^{61}$ Eric Forner, Free Soil, Free Labor, Free Men, 238-9.

62 Ibid., 240.

63 Kirwan, John J. Crittenden, 301.

64 “Presidential Election of 1856," http://www.270towin.com/1856 Election/, accessed 1/26/2015.
} 
American Party did not win Kentucky. Fillmore lost the state by over seven thousand votes, over 5 percent of the Kentucky popular vote, granting the Democrats their first presidential victory in Kentucky in over twenty years. ${ }^{65}$ Former southern Whigs saw Buchanan's victory not as a solution to sectional politics, but as a holding action that only postponed the question until the 1860 election. ${ }^{66}$

In Kentucky, George D. Prentice, editor of the Journal, and Garrett Davis, former congressman and Whig political leader, led the charge for the American Party and vehemently fought Democratic claims that it included abolitionists. ${ }^{67}$ In 1855 , Kentucky Know-Nothings supported Charles S. Morehead for governor, as did Davis and Crittenden. Morehead won the state by 4,400 votes, and six of ten Know-Nothing congressional candidates won election. Forty of the former Whig counties that had voted for Scott in the 1852 presidential election went for Know-Nothings. ${ }^{68}$ The state vote revealed the continuity between the collapsing Whig party in Kentucky and the American Party, the persistence of voter loyalty, and the ability of former Kentucky Whigs to organize effectively.

Know-Nothingism proved controversial in Kentucky in the 1860 election. The state Constitutional Union attempted to claim the American Party mantle several times, and in an article titled, "The Fillmore Men," the Journal claimed the support of Fillmore and the American Party as a national union party. ${ }^{69}$ Certainly some prominent Kentucky Know-Nothings, including Garrett Davis and Charles Morehead, supported the Constitutional Union Party. However, both

\footnotetext{
65 "1856 Presidential General Election Results: Kentucky," http://uselectionatlas.org/RESULTS/state.php?fips=21\&year=1856\&f=0\&off=0, accessed 1/28/2015.

${ }^{66}$ Cole, Whig Party in the South, 326.

${ }^{67}$ Kirwan, John J. Crittenden, 298.

68 Ibid., 300.

69 “The Fillmore Men," Louisville Weekly Journal, June 13, 1860.
} 
Constitutional Unionists and Democrats attempted to distance themselves from the nativism of the Know-Nothings. On July 25, the Journal accused Breckenridge of nativism and KnowNothing membership. ${ }^{70}$ Breckenridge responded to charges of nativism in his speech near Ashland on September 5, 1860, claiming to have "never uttered such a sentiment."71 The Courier, a Breckenridge ally, regularly applied the Know-Nothing label to Bell, referring to him as the "Know-Nothing Candidate for President," and his party as the "Know-NothingOpposition-Union Party," highlighting the political path traveled by many former Whigs in these three successor organizations. $^{72}$

In 1856 , the American Party became the temporary ally and political home of prominent conservative Border South Whigs such as Davis, Bell, and Crittenden. Four years later, these men became leaders of the Constitutional Union Party in Kentucky. When the American Party collapsed along sectional lines, these political actors and their voters again searched for a new home. In Kentucky and the Upper South, they gravitated to what became known as "The Opposition," maintaining a significant political influence. But the turmoil benefited Kentucky Democrats who began to gain ground in Kentucky in the 1850s. In 1859, Democrat Beriah Magoffin defeated former Whig and Oppositionist candidate Joshua Bell by over nine thousand votes in the gubernatorial race, and Democrats claimed six of ten of Kentucky's U.S. House seats. ${ }^{73}$ Democratic gains prompted the Kentucky Opposition to seek a new political organization in 1860: the Constitutional Union.

\footnotetext{
70 “John C. Breckenridge-Know-Nothingism," Louisville Journal, July 25, 1860.

71 John C. Breckenridge, September 5, 1860, Speech Near Ashland, Filson Historical Society, Louisville, KY.

72 "Bell to Breckenridge," Louisville Courier, October 27, 1860. “He Didn't Answer," Louisville Courier, September 22, 1860.

${ }^{73}$ Kirwan, John J. Crittenden, 341.
} 
Growing sectional turmoil over slavery in the final three years of the 1850 s convinced former conservative Whigs of the need for a new national party. In 1857, the Buchanan administration and allied Democrats hoped that the Supreme Court would resolve the slavery issue. In Dred Scott vs. Sanford, Scott, a slave who had lived in the free states of Illinois and Wisconsin, sued for his freedom after the death of his master. The Supreme Court ruled that African Americans were not citizens and therefore Scott could not sue for freedom. The Court added that the federal government could not regulate slavery in the territories. The Court's decision, rather than resolving the debate, sparked anger in the North among Republicans as well as Democrats. In contrast, southern Democrats welcomed the discussion, and in the election of 1860 in Kentucky, Breckenridge campaigned on the support of Dred Scott and claimed his position on the expansion of slavery constitutionally supported by the highest court in the nation. $^{74}$

The sectional situation became more dire when Kansas applied for statehood under the proslavery Lecompton Constitution. Though it represented the opinion of only proslavery Kansans, the constitution received the endorsement of the Buchanan administration and southern Democrats. But a coalition of congressional Republicans and northern Democrats, led by Stephen Douglas, denied Kansas's application for statehood under Lecompton. Bell, Crittenden, and many former southern Whigs who became Constitutional Unionists joined the northern representatives in voting against Lecompton. ${ }^{75}$ The failure of the proslavery constitution further angered southern Democrats and inflamed sectional tension within the party. In the election of

\footnotetext{
74 John C. Breckenridge, "Speech of John C. Breckenridge at Ashland," September 5, 1860, FHS.

${ }^{75}$ Kirwan, John J. Crittenden, 326-32.
} 
1860, Kentucky Democrats charged Bell and the Constitutional Unionists with abandoning the interests of slavery and the South with their votes against Lecompton.

The escalating battle over slavery culminated in violence. On October 16, 1859, John Brown, a radical abolitionist who had massacred proslavery men at Pottowatamie, Kansas, in 1856, led a raid on the federal armory at Harpers Ferry, Virginia. Brown intended to raid the armory, arm local slaves, and incite a slave rebellion in the South. The plan failed, and the state of Virginia executed Brown for treason, inciting a slave insurrection, and murder. ${ }^{76}$ Harpers Ferry confirmed southerners' fears of northern antislavery aggression. Border State Oppositionists, former Whigs, and future Constitutional Unionists loudly condemned Brown, antislavery men, and northern radicals. ${ }^{77}$ Brown's raid ruined hopes of men like Crittenden who hoped to fuse with conservative Republicans in a new national party.

Without significant northern support, the Border State "Opposition" supplied most of the political leaders and voters of the Constitutional Union Party in 1860. In Kentucky, the party's supporters were mainly former Whigs who had moved into the ranks of the American Party after the Whig collapse and then to the Opposition. Support of men such as Davis, Charles Morehead, and Crittenden who had traveled this path in the 1850 s ensured credibility in the state. These former Whigs brought Bell the backing of organs such as the Kentucky Whig and the Louisville Journal, along with voter support in former Whig strongholds such as the inner Bluegrass (Lexington), Louisville, and the western coalfields (Owensboro and Henderson). This crucial base of support served as the first ingredient of Bell's electoral victory in Kentucky. As one

\footnotetext{
${ }^{76}$ William A. Link, Roots of Secession: Slavery and Politics in Antebellum Virginia (Chapel Hill, NC: University of North Carolina Press, 2003), 179-85.

77 Ibid., 194.
} 
correspondent predicting the result of the election in Kentucky wrote, "Mr. Bell will carry the state by several thousand plurality, and I hope all the Whigs will stand by him.",78

\section{The Rise of the Constitutional Union Party}

In 1860 , in response to a decade of tumult and increasing sectional conflict over slavery, old conservative Whigs organized a new national party. The party attracted respected politicians such as John Bell, John J. Crittenden, Edward Everett of Massachusetts, John P. Kennedy of Maryland, William Graham of North Carolina, and William Rives of Virginia who had long careers in the Senate, presidential administrations, and state governors' offices. ${ }^{79}$ These men had considered joining a national union party in 1850 , witnessed the collapse of their Whig Party in 1854, and placed their hopes on the American Party in 1856. They resisted joining their old rivals, the Democrats, and their new foes, the northern sectional Republican Party. They sought a new organization to contest what many considered the most important presidential election in history. As Leslie Combs, former Kentucky Whig Congressman wrote, "May God save the country and our liberties and damn all who lack Unionism." 80

The idea of a national union party had been discussed in 1850 , and men such as Crittenden and Bell had hoped the American Party would fit this description in 1856. This vision would be realized in the Constitutional Union Party in 1860. In 1859, Nathan Sargent, a Whig political strategist, publisher, and newspaper editor from New York began to organize a national union party with the goal of appealing to Border South Oppositionists like Crittenden and

\footnotetext{
78 Letter from Cambridge to Kentucky, July 29, 1860, Duncan Family Papers, Margaret King Library, University of Kentucky, Lexington, KY. Hereafter UKL.

${ }^{79}$ Nevins, The Emergence of Lincoln, Volume II, 261,

80 Leslie Combs to John J. Crittenden, March 15, 1859, John J. Crittenden Papers, UKL.
} 
conservative Republicans who had once belonged to the Whig Party. ${ }^{81}$ The same year, Crittenden worked within Congress to organize a national union party from the top down. He hoped to gain the support of former Whigs looking for a new party, conservative Republicans, and some moderate Democrats. ${ }^{82}$ Crittenden thought he could win over many moderate Whigsturned-Republicans who had pledged their support to the new party because of its stances on issues like the tariff. In early 1859, Prentice and Crittenden both thought it possible that Republicans might abandon their ardent antislavery views and fuse with them to win the election. ${ }^{83}$ However, John Brown's raid on Harpers Ferry in October, and continued antislavery agitation made fusion with the Republicans impossible for the Border State Oppositionists. Republicans also sensed that they might win outright and thus would not temper their antislavery views to effect a national fusion. ${ }^{84}$

Despite this setback, Constitutional Union leaders continued to organize. On May 9-10, 1860, the party held a national convention in Baltimore and nominated the first presidential candidate of the election. The convention formally represented both the American Party and the Whig Party. ${ }^{85}$ This convention constituted "the closest thing to a resurrected Whig Party that was imaginable in the final months of the Antebellum Republic." ${ }^{86}$ Crittenden, the party organizer, served as the keynote speaker. He wanted the party to "serve the interests of the whole country...combat sectional animosity... and [unite] the conservative men of the country." 87 The convention elected Washington Hunt, former Whig governor of New York and congressman as

\footnotetext{
${ }^{81}$ Cole, Whig Party in the South, 333.

82 Ibid., 337-8.

${ }^{83}$ Kirwan, John J. Crittenden, 357.

${ }^{84}$ Cole, Whig Party in the South, 336.

${ }^{85}$ Louisville Weekly Journal, May 12, 1860.

${ }^{86}$ Ashworth, Slavery, Capitalism and Politics in the Antebellum Republic," 593.

${ }^{87}$ Louisville Weekly Journal, May 12, 1860.
} 
president. Hunt urged the delegates to "know no Party but our Country and no platform but the Union." 88

As at most antebellum political conventions, delegates put forward a variety of candidates for president including notable men such as Graham of North Carolina, Everett of Massachusetts, and Edward Bates of Missouri. Ultimately, only three men proved serious contenders: Bell, Houston, and Crittenden. The nomination was Crittenden's for the taking, but he let delegates know before the convention that he did not wish to be considered due to his age. ${ }^{89}$ With Crittenden bowing out, the nomination came down to Bell or Houston. Crittenden opposed the nomination of Houston because of the latter's long friendship with Andrew Jackson and his Democratic career. ${ }^{90}$ Having the party leader Crittenden on his side greatly aided Bell's cause.

Nonetheless, Bell's nomination was not a foregone conclusion. Seeking to be the people's candidate, Houston had started a grassroots movement and hoped to have the support of New York, Alabama, Georgia, and possibly Kentucky (pending Crittenden's decision to decline) heading into the convention. ${ }^{91}$ The Journal praised Houston as a "true champion of the Constitution and the Union." 92 Houston also offered the allure of popularity. Writing to relatives in Kentucky from Madisonville, Texas, one (future) Breckenridge supporter wrote that "If old Sam Houston would be a candidate...he will likely carry Texas, at least I am afraid so."93

Despite Houston's popular allure, the old Whigs in the Constitutional Union nominated Bell, one

\footnotetext{
88 Ibid.

${ }^{89}$ Fuller, The Election of 1860 Reconsidered, 113-4.

${ }^{90}$ Egerton, Year of Meteors, 91.

${ }^{91}$ Parks, John Bell of Tennessee, 352-5.

92 Louisville Journal, May 12, 1860.

${ }_{93}$ Madisonville, Texas to Kentucky relatives, April 21, 1860, Boyd, Wherrit, and Wilson Family Papers, Kentucky Historical Society, Frankfort, KY. Herafter, KHS.
} 
of their own. On the first ballot, Bell received 68 and a half votes, Houston 57, Crittenden (despite his protest) 28 (including the Kentucky delegation), and Everett $25 .^{94}$ Tennessee, Arkansas, Pennsylvania, Ohio, and Delaware backed Bell. On the second ballot, Virginia delegates marshalled support for Bell as a trustworthy, conservative Whig, Crittenden delivered the Kentucky delegates, and Bell won the nomination 138 to 69 over Houston. ${ }^{95}$

To balance the ticket and give it a national character, the party nominated Everett for vice president. A conservative Whig in the same vein as Henry Clay, Everett served as governor of Massachusetts, a United States Senator, and the secretary of state under Fillmore. ${ }^{96}$ Despite some misgivings, Everett accepted the nomination, writing to Convention President Washington Hunt that he hoped to fight the "sectional characteristics of a fearful struggle between the North and South." 97

The primary Whig-American-Oppositionist, now Constitutional Union organ in Kentucky, the Louisville Journal, wholeheartedly unfurled the Bell-Everett banner in its pages. On May 12, it proclaimed, "We ratify this nomination with our whole heart. John Bell is worthy to be President of the United States...he will be a pure and honest man, is a statesmen of experience and of tried tenacity and a patriot of unspotted loyalty." 98 Two days later the paper exclaimed, "I think I speak for the voice of Kentucky when I say that John Bell claims her devoted respect next to John J. Crittenden." 999 Former Kentucky Whigs, political leaders, and newspapers fervently supported the nomination of Bell. Kentucky Constitutional Unionists held

\footnotetext{
94 Parks, John Bell of Tennessee, 353-5.

$95 \mathrm{Ibid}$. After Bell won the nomination, the convention made his nomination unanimous.

${ }^{96}$ Fuller, The Election of 1860 Reconsidered, 117.

97 “Mr. Everett Accepts," Louisville Weekly Journal, June 13, 1860.

98 Louisville Weekly Journal, May 15, 1860.

${ }^{99}$ Louisville Weekly Journal, May 22, 1860.
} 
a large and "enthusiastic" ratification meeting to celebrate the Bell-Everett ticket and officially kick off the campaign in early July. ${ }^{100}$

Many historians, including Bell's own biographer, have viewed the selection of Bell as at best unexciting and at worst unwise for the Constitutional Union. Historian Joseph Howard Parks calls Bell "much admired and respected but little loved." ${ }^{\prime 01}$ But the Constitutional Union Party's desire to calm sectional tensions and bridge the divide over slavery required a man of Bell's experience and proven statesmanship. Sixty-four at the time of the election, Bell's age highlighted the Constitutional Union Party's strength of seasoned experience and statesmanship. Bell had served as Speaker of the U.S. House of Representatives in 1834-35, as Secretary of War, and as a U.S. Senator for more than a decade from $1847-1859 .{ }^{102}$ He participated in the great congressional debates of the 1850 s, including the Compromise of 1850 , the KansasNebraska Act, and the Lecompton Constitution. Each time, Bell voted with the interest of national union at heart. Many voters may have viewed Bell as an old statesmen lacking consistent principles with regard to slavery, but a large plurality of Kentuckians put their faith in Bell's proven record, experience, and national rather than sectional voting record.

Despite historians' assertions, Bell's campaign generated notable excitement. Just as the Lincoln campaign inspired young “wide-awake” demonstrators, Bell's young supporters were known as the "Bell Ringers" after the practice became popular at Constitutional Union campaign rallies. ${ }^{103}$ Women too supported the Bell-Everett campaign in large numbers, carrying on a Whig tradition of female attendance of speeches. Women's Whig loyalties ensured that the Bell

\footnotetext{
100 "Bell and Everett Grand Ratification Meeting-Campaign Opened," Louisville Weekly Journal, July 11, $1860,1$.

101 Parks, John Bell of Tennessee, 358.

102 Ibid. Entire Work.

${ }^{103}$ Louisville Weekly Journal, May 15, 1860, 2.
} 
campaign received more female support than any other candidate in $1860 .{ }^{104} \mathrm{Joseph} \mathrm{F}$. Scott, writing from Harrison County, Kentucky, described Bell men as more optimistic and excited compared to Breckenridge supporters in the commonwealth. "The Breckenridge men," Scott wrote, "seem to be rather down in the mouth while the Bell men are reverse." 105 If Bell proved, victorious, Scott planned to purchase a bust of the Tennessee senator. ${ }^{106}$ Writing to Kentucky from Massachusetts, Leverett Saltonstall described the Constitutional Union Party in his state as "rapidly gaining ground [and] full of enthusiasm." ${ }^{107}$ Evidence from the Journal and Kentucky correspondents reveals that Bell generated support and even excitement among voters in the Commonwealth.

With sectional conflict looming, the Constitutional Union Party did not adopt a traditional party platform at its convention. Disavowing parties as "sectional," the party recognized "no political principle other than the Constitution of the Country, the Union of the States, and the Enforcement of the Laws." ${ }^{108}$ In a statement released shortly after the convention, the party accused the Democrats and Republicans of using slavery as a political tool to gain power at the expense of national unity. To preserve the nation, they advocated "removing the subject of slavery from national politics and leaving it to the control of states in which it exists." 109 The party thus refused to take a stance on the primary issue of the day to facilitate compromise and national unity. Party leaders also declined to weigh in on other partisan issues including the tariff. Despite the support of Pennsylvania and Tennessee delegations for a

\footnotetext{
${ }^{104}$ Egerton, Year of Meteors, 189. Elizabeth Varon, We Mean to Be Counted: White Women in Politics in Antebellum Virginia (Chapel Hill, NC: University of North Carolina Press, 1998).

105 Joseph Scott to My Dear Friend, July 8, 1860, FHS.

106 Ibid.

${ }^{107}$ Leverett Saltonstall to Hon. John F. Henry, September 7, 1860, FHS.

108 John Wooley and Gerhard Peters, "Constitutional Union Party Platform of 1860,"

http://www.presidency.ucsb.edu/ws/?pid=29571, accessed 1/25/2015.

${ }^{109}$ National Committee of the Constitutional Union Party, "To the People of the United States," 1860, 1-5.
} 
protective tariff plank, the convention decided to put aside all partisan issues and make national unity its priority. ${ }^{110}$ The platform's ambiguity became a key point of political debate during the 1860 campaign nation.

The composition, platform, and candidate of the Constitutional Union Party ensured the electoral support of many Kentuckians in the election of 1860. The Constitutional Union Party's leaders were the sort of Border State Whigs that Kentuckians had long supported. The party, as the political inheritor of the conservative Whiggery of Henry Clay, found a ready voter base in Kentucky, long a Whig stronghold. Kentucky had voted for Whig presidential candidates in every election between 1832 and 1852, and the state gave Bell their support in 1860 as he took back up the Whig mantle. Bell represented the Border South Whig tradition that had strong popular support in Kentucky. The election of 1860 centered on the issues of national union and slavery. The voters of Kentucky opted for experienced statesmanship, compromise, union, and the protection of slavery.

\section{The Challengers}

The election of 1860 featured three primary candidates in addition to Bell. The Democratic Party split along sectional lines and nominated two candidates, Vice President John C. Breckenridge of Kentucky became the southern nominee and Illinois Senator Stephen A. Douglas was the northern candidate. The Republican Party chose former Illinois Congressman Abraham Lincoln, and it conducted its campaign almost entirely in the North. Two minor candidates also ran in the election. Denied the Constitutional Union nomination, Sam Houston received the nomination of the People's Party, but his campaign floundered. The abolitionist Liberty Party also contested the

\footnotetext{
${ }^{110}$ Parks, John Bell of Tennessee, 353-5.
} 
election, but Gerrit Smith, a John Brown supporter and former congressman of New York, only received a smattering of votes nationally. In Kentucky, the race centered on Breckenridge and Bell, but Douglas received roughly twenty-five thousand votes, damaging the Breckenridge campaign and opening the door to a Bell victory. The votes Douglas stripped away from Breckenridge due to the Democratic split were the second ingredient in Bell's winning formula.

As the 1860 Democratic National Convention approached, agitation over slavery and inter-party strife threatened to split the party. The Dred Scott decision emboldened southern slavery expansionists to call for constitutional protection of slavery everywhere in the United States. President Buchanan, Chief Justice Taney, and southern ultras hoped that the Supreme Court decision would settle the slavery issue permanently in the South's favor, and southern Democrats pushed for the acceptance of the proslavery Lecompton Constitution in Kansas. Douglas, the leader of the northern Democracy, successfully organized against the acceptance of Lecompton, and emboldened southern Democrats deemed him an unacceptable candidate for president in $1860 .{ }^{111}$ Southern ultras, touting Dred Scott, embraced a radical doctrine of slavery expansion just three short years after they had voted for popular sovereignty in the KansasNebraska Act. After their Supreme Court victory, they no longer accepted popular sovereignty, decrying it as a threat to the existence of slavery. Southern Democrats, heading into the 1860 Charleston National Convention, would not accept Stephen Douglas or the popular sovereignty pronouncements embodied in his Freeport Doctrine which stated that citizens of a territory may still prohibit slavery in spite of Dred Scott. ${ }^{112}$

\footnotetext{
111 Egerton, Year of Meteors, 55.

112 Ibid., 54.
} 
From April 23 to May 3, 1860, Democrats met in Charleston, South Carolina, to nominate their presidential candidate and write a platform. The convention was doomed to failure when most southern Democrats, led by Alabama fire-eater William Lowndes Yancy, refused any concessions to northern Democrats. ${ }^{113}$ Antiquated convention rules did not help the cause of reconciliation. Two-thirds of the delegate present had to support the candidate who won the nomination. Delegates were apportioned by electoral college vote, giving the weaker, northern wing of the party a disproportionate amount of power, while the platform and resolution committee better reflected the power of the South. ${ }^{114}$ The over-representation of the North gave Douglas a fair chance to win the nomination, but the resolution committee rules ensured that the majority platform proposal reflected southern interests. ${ }^{115}$ Either the northern Democrats had to yield on Douglas or give the South their platform.

The first battle erupted over the platform. The committee split across sectional lines and could not reach a consensus. Northern Democrats issued a minority platform that echoed the 1856 statement and left room for popular sovereignty and Douglas's Freeport Doctrine. Southern Democrats published a majority platform that adopted Yancey's southern ultra position. ${ }^{116}$ After long debate, the convention accepted the minority platform of the northern Democrats, and most southerners began to walk out. ${ }^{117}$ However, Kentucky and Tennessee delegates remained, and Kentuckians attempted to extend the convention in hopes of reaching a compromise. ${ }^{118}$ The Louisville Journal condemned the southerners who walked out, labeling them disunionists and

\footnotetext{
113 Ibid., 52-3

114 Ibid., 66.

115 Ibid.

116 Ibid., 72.

117 Ibid., 76.

118 Ibid., 81.
} 
their meeting the "seceders' convention." 119 The paper gladly pronounced the end of their Democratic foe: "Funeral Notice: It is with great pain that we record the death of the Democratic Party." 120

Even after the southern walk out, a compromise at Charleston remained possible. Kentuckian James Guthrie, secretary of the treasury in the Pierce administration, emerged as a dark horse candidate acceptable to Border South Democrats. Early in 1860, both Democratic papers in Louisville, the Courier and the Democrat, supported Guthrie for the nomination, and the Journal argued that if Guthrie received the Democratic nomination he would carry Kentucky. ${ }^{121}$ The Kentucky Whig newspaper stated that "Mr. Guthrie would be supported by the Whigs and Americans of the state." ${ }^{122}$ Guthrie purportedly returned the favor by endorsing the Bell and Everett campaign in July. ${ }^{123}$ Guthrie had the support of moderates at the convention, but over fifty ballots later, no candidate could break the two-thirds threshold as Douglas men refused to back down to southern pressure. When southern men agreed to meet in Richmond in June, the remaining Democrats set a new convention date for June 18 in Baltimore. These delegates also decided that states should replace the seceding delegations in Baltimore. ${ }^{124}$

As June 18 approached, southern state parties refused to select new delegates and instead sent the Charleston seceders to Baltimore. Indeed, South Carolina and Florida officially declined to send delegates to Baltimore, instructing them to go to Richmond although many would attend both conventions. ${ }^{125}$ Like the convention stage that collapsed on the first day, so the convention

\footnotetext{
119 Louisville Weekly Journal, May 12, 1860.

120 "Funeral Notice," Louisville Weekly Journal, May 22, 1860.

121 Price, Charles B. Jr., "The Storm of Disunion over a Border State," Chapter 2, 7-12, FHS.

122 "Honorable James Guthrie," Louisville Weekly Courier, April 19, 1860.

123 "Kentucky Politics-Guthrie," Louisville Weekly Journal, July 4, 1860.

124 Egerton, Year of Meteors, 156-8.

125 Ibid.
} 
would fall apart as a result of these delegations. The credentials committee could not decide on which delegates to seat. Georgia sent two delegations, other southern states had failed to appoint new delegates, and South Carolina and Florida had not sanctioned their delegates to attend the Baltimore convention. The credentials committee submitted two reports. When the northern Democracy's report carried the vote, southern delegates walked out a second time. ${ }^{126}$ Kentucky delegates remained the rest of the day after other slaveholding states delegations had left, but the next day they joined their fellow slave state Democrats. ${ }^{127}$

The second convention finalized the rift between southern and northern Democrats. At Baltimore, the northern Democrats quickly nominated Douglas and adopted the 1856 platform while southern Democrats selected Kentuckian and Vice President Breckenridge on the Yancey platform. ${ }^{128}$ The Kentucky delegates attempted to strike a compromise and keep the party together, but ultimately joined their fellow slaveholding states. The Democratic Party split opened the door for the Bell campaign in Kentucky. Most state Democrats embraced its favorite son Breckenridge, but a significant minority supported Douglas. In short, while Bell enjoyed the support of erstwhile Kentucky Whigs/Americans/Oppositionists, he faced a weaker opponent after the Democratic split.

Northern Democrat Stephen Douglas espoused national union and compromise, but failed to gain traction in Kentucky despite voters' attachment to union. Several factors undermined Douglas's campaign in the state. Douglas struggled in all the slaveholding states because of his support for popular sovereignty which, after the Dred Scott decision, southerners viewed as an

\footnotetext{
126 Ibid., 163.

127 Ibid., 164.

${ }^{128}$ Ibid., 168.
} 
antislavery position. ${ }^{129}$ In a speech at Ashland on September 5, 1860, Breckenridge argued that no "responsible political party" could hold the opinion that the citizens of a territory or a territorial legislature could exclude slave property pending territorial status. ${ }^{130}$ The Journal also criticized Douglas's "squatter sovereignty" and labeled him a "northern sectionalist."131 The state's Breckenridge Democrats, the paper added, viewed Douglas's popular sovereignty as “cowardly abolition[ism]."132 Kentuckians' commitment to slavery even in non-slaveholding regions hurt the Douglas campaign. The Illinois Senator's opposition to the proslavery Lecompton Constitution, endorsed by Breckenridge, Buchanan, and southern Democrats, further alienated him from the southern wing of the party. ${ }^{133}$ Though Bell too had voted against Lecompton, as a former Whig with primarily former Whig supporters, his vote did not hurt him as much because of Lecompton's association with Democrats. Further, Bell supporters praised him as the only consistent opponent of popular sovereignty and the Kansas Nebraska Act in the race. $^{134}$

The fact that Breckenridge, a former Kentucky congressman from Henry Clay's Ashland district, was a local favorite candidate and knew the Kentucky Democratic machinery unquestionably hurt Douglas's prospects in Kentucky. The Journal predicted that with Breckenridge's nomination by Richmond delegates, Douglas would “cut a very slender figure here as in the south generally."135 The belated walkout of the Kentucky delegates at Baltimore foretold the stance of most Democratic voters in the state.

\footnotetext{
${ }^{129}$ Robert W. Johannsen, "Stephen A. Douglas and the South," The Journal of Southern History 33 (1964): 34-6.

130 John C. Breckenridge, "Speech at Ashland," September 5, 1860, FHS.

131 "The Duty of all National Men," Louisville Weekly Journal, July 4, 1860.

132 Louisville Weekly Journal, July 4, 1860.

133 Johannsen, "Stephen A. Douglas and the South," 34-6.

134 "The Disunion Party: A Direct Avowal," Louisville Weekly Journal, August 15, 1860.

135 Louisville Weekly Journal, June 27, 1860.
} 
Still, Douglas did not lack friends and supporters in the commonwealth. Kentuckian H. Marshall believed that Douglas could win the state after traveling throughout the Jackson Purchase in the western part of the state. ${ }^{136}$ Douglas received the endorsement of a major Democratic paper, the Louisville Democrat, and he even made a campaign stop in Louisville. ${ }^{137}$ According to one member of the Frost Family of Lexington:

The Lexington Democracy is split all to pieces. As soon as the news from Baltimore was received, the Lexington Statesman came out with the names of Breckenridge and Lane at the head of the columns and an editorial in their favor. [Yet] Douglas has many friends in this section. $^{138}$

The divided Democracy, particularly in the city of Louisville, greatly aided Bell's cause. According to Bradley Bodley, "In the town [Lexington] Douglas will receive about one and a half or two votes to B[reckenridge]'s one, while Breck will receive five out of six votes in the county." 139 Bell's victory owed much to the division within Kentucky's Democracy. A united Kentucky Democracy had defeated the Oppositionist candidate, Joshua Bell, by nearly nine thousand votes in the 1859 gubernatorial race, placing Beriah Magoffin in office. ${ }^{140}$ Douglas captured 25,651 votes or 17.5 percent of the total in Kentucky. If Douglas had not garnered Democratic votes, Breckenridge could have defeated Bell by over ten thousand votes. ${ }^{141}$ The Democratic split in Kentucky aided the Bell campaign, opening the door for his comfortable margin of victory in Kentucky.

\footnotetext{
${ }^{136} \mathrm{H}$. Marshall in Memphis to recipient, July 8, 1860, Marshall Family Papers, FHS.

${ }^{137}$ Crenshaw, The Slave States in the Presidential Election of 1860, 74-84.

${ }^{138}$ Frost to Mr. Buhridge (a friend), July 2, 1860, FHS.

${ }_{139}$ Col. Bradley Bodley to his Brother, July 12, 1860, Bodley Family Papers, FHS.

140 Kirwan, John J. Crittenden, 341.

141 "1860 Presidential General Election Results: Kentucky,"

http://uselectionatlas.org/RESULTS/state.php?fips=21\&year=1860\&f=0\&off=0, accessed 1/27/2015.
} 
In the South, the Douglas campaign entertained ideas of fusion with the Constitutional Union campaign, following the example of fusion tickets in New York and New Jersey. ${ }^{142}$ The two tickets did not fuse in Kentucky, but they reached an entente cordial or friendly agreement. ${ }^{143}$ The pro-Douglas paper, the Louisville Democrat, attacked the Breckenridge campaign and its Louisville organ, the Courier, much more fiercely than it attacked the Bell campaign. ${ }^{144}$ The Courier referred to Bell and Douglas supporters as "compatriots" and claimed that Bell-Everett men made up the majority of attendees at a pro-Douglas rally in Louisville. ${ }^{145}$ The Courier repeatedly charged that the entente cordial attacked Breckenridge with false allegations. ${ }^{146}$ Still, the Bell and Douglas campaigns in Kentucky sometimes clashed, as when the Journal noted, "Those who admire Douglas have a contempt for dignity and those who admire dignity have a contempt for Douglas." ${ }^{147}$ However, as the election approached, the Bell and Douglas campaigns directed their ire primarily at Breckenridge.

The unpopularity of popular sovereignty, Breckenridge's favorite son status, and the secession of the Kentucky delegation from the Baltimore convention, led the majority of the divided Kentucky Democratic Party to support Breckenridge who had served two terms in the House from 1851 to 1855, representing Henry Clay’s former Ashland district. In 1857, at age thirty-six, he became the youngest vice president in the nation's history after running with James Buchanan. ${ }^{148}$ Breckenridge had a reputation as a friend of the slave states, but he was not seen as a southern ultra or radical. As a member of the Buchanan administration, he pushed for the

\footnotetext{
142 Johannsen, "Stephen A. Douglas in the South," 47.

143 Park, John Bell of Tennessee, 373.

144 Price, "The Storm of Disunion Over a Border State," 20, FHS.

145 "The Great Douglas Meeting," Louisville Weekly Courier, August 4, 1860.

146"Beware of Disunion," Louisville Weekly Courier, August 11, 1860.

147 Louisville Weekly Journal, May 30, 1860.

148 Egerton, Year of Meteors, 150.
} 
Lecompton Constitution and the congressional protection of slavery in the territories after Dred Scott. ${ }^{149}$

Breckenridge lacked the reputation as a southern ultra, but he accepted the nomination of the Democratic faction led by radical proslavery southerners such as William Lowndes Yancey and Robert Barnwell Rhett. The platform Breckenridge ran on and the majority of the Kentucky Democracy supported reflected the politics of Yancey and advocated for protection of slavery in the territories:

The Government of a Territory is temporary. During its existence, all citizens of the United States have an equal right to settle with their property in the territory....It is the duty of the Federal government, in all its departments, to protect the right of persons and properties in the Territory. ${ }^{150}$

Breckenridge's association with southern ultras, coupled with a decade of debate over slavery capped by John Brown's raid on Harpers Ferry in October 1859, placed the issues of union and slavery at the forefront of the 1860 election. The rhetoric of Union and slavery enabled Bell to garner the support of Kentucky voters and win the state's electoral votes.

The 1860 presidential race in Kentucky followed the pattern of slave states identified by historians such as E.D. Fite, Ollinger Crenshaw, and James Fuller. Breckenridge and Bell were the primary contenders that emerged, despite a fairly significant faction of Douglas supporters in the state. Notwithstanding the state's modern fondness for Lincoln, as a candidate in 1860 he gained only 1,364 votes accounting for 0.93 percent of the total. ${ }^{151}$ Lincoln and the Republican

\footnotetext{
149 Fite, The Presidential Campaign of 1860, 153.

${ }^{150}$ Ibid., 241-2.

151 "1860 Presidential General Election Results: Kentucky,"

http://uselectionatlas.org/RESULTS/state.php?fips=21\&year=1860\&f=0\&off=0, accessed 1/25/2015.
} 
Party's association with antislavery made them an object of fear and scorn among Kentucky Constitutional Unionists and Democrats alike.

In 1859, while exploring the idea of working with conservative Republicans, Crittenden seems to have contacted Lincoln, a former moderate Whig, about the Constitutional Union Party nomination for $1860 .{ }^{152}$ Crittenden and other Constitutional Unionists likewise vetted Edward Bates of Missouri, a former Whig who sought the Republican nomination in 1860 at Chicago. ${ }^{153}$ Nonetheless, Constitutional Unionists in Kentucky attacked Lincoln after he accepted the Republican nomination over the more radical antislavery former governor of New York, William Seward. They assailed Lincoln and his party on charges of abolitionism and dangerous northern sectionalism. Just as they linked Breckenridge and disunionism, Constitutional Unionists in Kentucky often charged Lincoln with abolitionism through guilt by association. Republicans, noted Garrett Davis, had a "fanatical hatred of slavery" and Lincoln, although perhaps a moderate, also harbored "hostility" to the peculiar institution. ${ }^{154}$

The southern claim that the Republican Party intended to destroy slavery where it presently existed found no support in the Republican Party's platform in 1860, and most Republicans vocally condemned the actions of radical abolitionist John Brown at Harpers Ferry. But the Republican platform endorsed a strong free-soil ideology stating, "We [the Republican Party] deny the authority of congress or a territorial legislature or any individual to give legal existence to slavery in any territory." The party's opposition to the extension of slavery convinced their opponents in Kentucky, both Constitutional Unionists and Democrats, that its members were abolitionists and dangerous sectionalists. Indeed, Daniel D. Barnard, a former

\footnotetext{
152 Kirwan, John J. Crittenden, 354.

153 Ibid.

154 “Letter of the Hon. Garrett Davis," Louisville Weekly Journal, July 25, 1860.
} 
New York Whig congressman, in what historian Allan Nevins deemed the most effective Constitutional Union pamphlet of the campaign, accused the Republican Party of eventual if not immediate abolitionism. ${ }^{155}$

In Kentucky, as throughout the rest of the South, all opposing parties began to use the "Black Republican" label. Lexington antislavery activist, politician, and printer Cassius Clay could not have been more wrong about Kentucky's views towards Republicans when he wrote that he "[had] no fears of carrying the state in 1860." ${ }^{156}$ Most Kentuckians' perceived the Republicans as a threat, an active danger to their way of life that had to be defeated. In fact, Republicans served more as an object of fear than a real political force in Kentucky. The Journal launched criticisms at the Republicans similar to those of the pro-Breckenridge Courier: "If the Black Republican Candidate shall be elected to the Presidency," the Journal declared in August of 1860 , "he will be expected to devote his whole time to 'rail splitting' for the Underground Railroad." 157 The Journal even declared that the success or failure of the Union depended on whether the Republicans could be defeated. ${ }^{158}$ The Courier attempted to tar Bell with the Republican label and damage his credibility among Kentucky voters. In an article titled, "Black Republican Sentiments," the Courier claimed that Bell was "mentioned by many Black Republicans in connection with the Chicago nomination."159

In Kentucky, Lincoln and the Republicans served as a group to be feared should they win election, but the party received minimal support. Douglas, as a result of the unpopularity of popular sovereignty and Breckenridge’s identity as a Kentucky Democrat, possessed no real

\footnotetext{
155 Nevins, The Emergence of Lincoln Volume II, 280.

${ }^{156}$ Cassius Clay to Cephas Brainerd, January 8, 1859, FHS.

157 "The South True to Union," Louisville Weekly Journal, August 15, 1860.

158 Louisville Weekly Journal, August 1, 1860.

159 "Black Republican Sentiments," Louisville Weekly Courier, October 27, 1860.
} 
chance of carrying Kentucky. However, Douglas received 17 percent of the vote, splitting the Democratic vote, and enabling Bell to claim victory. The election in Kentucky came down to a contest between Breckenridge and Bell as it did throughout the southern states, with Douglas acting as a spoiler. The contest would be decided on the issues of unionism and slavery as both men attempted to claim the mantle of Kentucky's great antebellum hero, Henry Clay.

\section{Chapter II: The Conduct of the Campaign in Kentucky}

\section{The Organizational Strategy of the Constitutional Union:}

Prominent politicians such as Crittenden, Washington Hunt, William Graham, John P. Kennedy, Bell, and Everett organized the Constitutional Union Party from the top down. They revived old conservative Whig politics and merged it with southern American Party men and border state "Oppositionists.” After issuing a call for true Union men to organize and appoint delegates, they nominated Bell and Everett at their Baltimore convention on the platform of the Union, the Constitution, and the Laws. However, the party required an overall national as well as state-level strategy and organization to succeed at subverting sectionalism and maintaining the Union.

From the outset, many national leaders of the Constitutional Union Party deemed outright victory unlikely. Instead, party leaders hoped to deny Lincoln a majority of the electoral college and send the election to the House of Representatives according to the process set forth in the twelfth amendment of the U.S. Constitution. ${ }^{160}$ If they could send the election to the House, a likely outcome given a divided Democratic Party and the virtual guarantee that no slave state would vote for Lincoln, Bell might win election as a compromise candidate, the second choice of most voters. The Journal enunciated this strategy and the belief that Bell would be elected by the

\footnotetext{
${ }^{160}$ Egerton, Year of Meteors, 88-9.
} 
House. ${ }^{161}$ In pursuit of this strategy, the Constitutional Union actively pursued fusion in certain states with the only other truly national candidate, Douglas. The Constitutional Union and National Democrats actively pursued fusion in New York and New Jersey in a largely failed effort to swing the states for Douglas and deny Lincoln an electoral college majority. ${ }^{162}$ Though the two campaigns did not fuse in the border states of Kentucky or Virginia, they did enter into an informal agreement to direct the majority of their ire at Breckenridge. ${ }^{163}$

The national strategy did not always mirror state level rhetoric or the expectations of many Constitutional Union voters. To excite voter enthusiasm and ensure a large turnout, politicians argued that Bell could win a majority of the electoral college outright or at least carry a large number of states in an effort to send the election to House. The Journal proclaimed that it had reliable information that Bell would carry states like Missouri and Alabama. ${ }^{164}$ Writing to Kentucky, a Constitutional Union operative dared to hope Bell might be elected outright by the voters. ${ }^{165}$ Blanton Duncan, a Constitutional Union elector from Kentucky in 1860 , did not seem to believe that Bell could win election by the people. However, he thought that Bell would win a good many states, certainly more than he did. Duncan declared, "Bell is certain to carry Virginia and North Carolina as well as Kentucky, Maryland, Delaware and Tennessee." He added that "in Mississippi the probability is decidedly for Bell."166 Duncan even doubted whether Breckenridge could carry Louisiana and Alabama. ${ }^{167}$ Most Constitutional Union voters in Kentucky believed

\footnotetext{
161 Louisville Weekly Journal, July 18, 1860.

162 Kirwan, John J. Crittenden, 358-60.

163 Ibid., 359.

164"Missouri Will go for Bell and Everett," Louisville Weekly Journal, September 5, 1860.

165 Leverett Saltonstall to John F. Henry, September 7, 1860, FHS.

166 Blanton Duncan to My Dear Captain, August 16, 1860, FHS.

167 Ibid.
} 
Bell would win many states, perhaps enough to win outright. In the event that he did not, they hoped fusion with Douglas would send the election to the House where Bell would be elected.

The Constitutional Union Party had several organizational advantages in Kentucky, especially the support of key state political leaders. Crittenden, in effect the national chairman of the party, had a long career in Whig politics, beginning in the state legislature, representing Kentucky in the United Senate, and occupying the governor's office in Frankfort. Davis, a former Whig congressman and American Party leader, also played an important role in the national organization of the Constitutional Union Party. Likewise, the party enjoyed the support of former Whig congressman and former Know-Nothing Governor Morehead. The support of these prominent politicians gave the Constitutional Union Party a large electoral base of former Whigs and American Party members along with their political connections. In addition, the Constitutional Union Party enjoyed the support of Kentucky Opposition newspapers, led by George D. Prentice's Louisville Journal, to disseminate the party’s message.

Nonetheless, the "new" party appears to have encountered some initial organizational problems. On July 20, the Journal implored its readers to organize as "local parties have yet to be formed" in most counties. ${ }^{168}$ Similarly, on July 4, the Journal asked the state committee of the party to better "organize its supporters around the commonwealth." ${ }^{169}$ Still, the Constitutional Union began to campaign for Bell and functioned as a typical antebellum political party. On July 11, Constitutional Union partisans held a large ratification demonstration in Louisville to support the nomination of Bell and Everett. ${ }^{170}$ Recognizing the political similarities of Kentucky and Tennessee, Constitutional Unionists began preparations to host a joint barbeque near the states'

\footnotetext{
168“Organize," Louisville Weekly Journal, June 20, 1860.

169 Louisville Weekly Journal, July 4, 1860.

170 “Bell and Everett Grand Ratification Meeting," Louisville Weekly Journal, July 11, 1860.
} 
shared border to celebrate their ticket. ${ }^{171}$ County and local branches of the party also planned festivals and barbeques in support of Bell. The "Union Men of Trigg, Lyon and Caldwell Counties" held a "Grand Union Festival" at Robert Palmer's springs on October 5. ${ }^{172}$ A mass Constitutional Union meeting took place at Mount Sterling on the same day. ${ }^{173}$ Local supporters, headed by Constitutional Union electors, led the canvass in large portions of the state. W.M. Fulkerson, a Bell elector, canvassed Jackson, Rockcastle, and Laurel Counties. Other electors and "assistant electors" stumped for Bell in Wolfe, Morgan, Magoffin, Bath, Rowen, Carter, Mason, Fleming, and Lewis Counties as well as in the city of Ashland. ${ }^{174}$ Electors and others conducted nearly a complete canvass of the state.

Party leaders traveled the state making public speeches on behalf of Bell and garnered much attention. Crittenden delivered the most important Constitutional Union speech of the campaign on August 2 to a packed audience at Mozart Hall in Louisville. ${ }^{175}$ Crittenden served as the most important spokesman for Bell in the state as the campaign continued. Morehead also campaigned on behalf of Bell and even took the Constitutional Union message to an Indiana demonstration. ${ }^{176}$ Kentucky Constitutional Unionists took an interest in the Indiana election, hoping to sway the state for Bell or Douglas by appealing to conservative Republicans. ${ }^{177}$ In accordance with antebellum tradition, Bell did not actively campaign, relying instead on his electors, local partisans, and prominent men such as Crittenden and Morehead to speak for him in the state.

\footnotetext{
${ }^{171}$ Louisville Weekly Journal, July 25, 1860.

172 Louisville Weekly Journal October 5, 1860.

173 Ibid.

174 Ibid.

175 John J. Crittenden, "The Union, the Constitution, and the Laws," August 2, 1860, FHS.

176 Louisville Weekly Journal, August 22, 1860, 2.

177 “Indiana," Louisville Weekly Journal, October 3, 1860, 1.
} 
In addition to demonstrations, barbeques, and speeches, written campaign materials served an important function in the party's campaign strategy. The Louisville Journal served as a campaign newspaper throughout the state. Following antebellum tradition, the paper served as an attack dog for Constitutional Unionists, frequently targeting Breckenridge and his "disunionist" friends and criticizing “Black Republicans." The Journal touted Bell's experience, emphasized unionism, and defended the candidate's proslavery record. It encouraged its readers around the state to increase the circulation of the paper and distribute it throughout their communities. ${ }^{178}$ They offered to mail copies to "Union Clubs" for twelve and a half cents per month if the club had five or more members, and for sixteen cents per month if less than five, for the duration of the campaign. ${ }^{179}$ The Journal's importance did not end at Kentucky's borders. It proved one of the most widely circulated papers in the slave states and "in no part of the country did anyone assume a stauncher unionist attitude." ${ }^{\prime 180}$ Another important campaign document of Kentucky Constitutional Unionists came in the form of John J. Crittenden's speech in Louisville titled "The Constitution, the Union, and the Laws." The Journal reproduced the speech and Prentice had it printed in pamphlet form and distributed to voters. ${ }^{181}$ Citizens of Louisville hung Constitutional Union flags and banners outside their homes. Constitutional Union supporters began using letterheads bearing a drawing of Bell along with envelopes with bells and the slogan "both bells have turned." 182 Other letterheads included the names of Bell electors in the commonwealth. ${ }^{183}$ In addition to these campaign materials, state Constitutional Unionists likely distributed

\footnotetext{
178 "Circulate the Journal," Louisville Weekly Journal, July 4, 1860.

179 Louisville Weekly Journal, June 20, 1860.

180 Ollinger Crenshaw, The Slave States in the Presidential Election of 1860, 164.

181 “A Noble Campaign Document," Louisville Weekly Journal. August, 1860.

182 Joseph F. Scott to Dick, August 8, 1860, FHS.

183 Blanton Duncan to Captain, August 16, 1860, FHS.
} 
materials produced by the national committee, including Bell and Everett campaign biographies, promotional fliers, and a letter addressed to the "People of the United States."

The Constitutional Union Party in Kentucky ran state level candidates in addition to the presidential ticket. For example, Leslie Combs ran in a statewide race for the clerk of the court of appeals on the Constitutional Union ticket. It also nominated some local candidates for offices such as sheriff. H. Bodley wrote to his brother about his nomination for sheriff by the Constitutional Union Party at a state convention. ${ }^{184}$ Leslie Combs, a former Whig politician and military general, defeated Breckenridge Democrat Clinton McClarty by 68,165 to 44,942 votes in the August race for clerk of the Kentucky court of appeals. ${ }^{185}$ The state level races served as an early indication of the strength of Constitutional Union support in Kentucky and the weakness of the divided Kentucky Democracy.

\section{Unionism: The Primary Campaign Issue}

As one traveler observed while visiting Kentucky in 1860, Kentuckians primarily discussed unionism and disunionism in connection with the 1860 election. ${ }^{186}$ The Bell campaign's primary tactic was to associate Breckenridge with disunionism and the southern sectionalist conspiracy to break up the Union, while portraying themselves as ardent defenders of the Union. This tactic proved extremely effective and contributed enormously to Bell's electoral victory in the state. Kentuckians' antebellum political culture celebrated deep attachment to the Union. ${ }^{187}$ Its greatest political hero was Henry Clay, the Great Compromiser. Clay earned a reputation for promoting national unity through his American system of internal improvements and early in his career he

\footnotetext{
${ }^{184} \mathrm{H}$. Bodley to his brother, July 18, 1860, Bodley Family Papers, FHS.

185 “The Official Vote of the State," Louisville Weekly Journal, September 12, 1860.

${ }^{186}$ Crenshaw, The Slave States in the Presidential Election of 1860, 164-5.

187 Ramage and Watkins, Kentucky Rising.
} 
championed the Missouri Compromise to settle sectional strife over slavery. His last great public act, the Compromise of 1850, shared the same national spirit. Some Kentuckians feared the radicalism of southern Democrats. According to Joseph Patterson, southern Democrats would rise to defend their "southern rights [slavery]" as they were "better fitted by nature to figure in the Fields of Mars than in the country of Cupid." 188

However, the Union did not serve merely as a sentimental positive for Kentuckians. The Union also promoted a whole host of practical benefits. Kentucky had deep economic ties to both the North and the South. With expanding railroads and the Ohio River connection to the Mississippi, Kentucky served as a crossroads of North-South commerce. ${ }^{189}$ Kentucky farmers sent hemp, their primary cash crop, along with slaves and northern manufactured goods south while they sent tobacco north by rail and canal. ${ }^{190}$ In the $1850 \mathrm{~s}$, more than nine out of ten Kentuckians worked on farms and relied on both northern and southern markets to absorb their surplus crop. ${ }^{191}$ Kentuckians feared a North-South split would greatly damage the state's economy. Moreover, as residents of a border state, Kentuckians feared that any conflict would pose great human costs and borders turned into battlegrounds. The pro-Union sentiments greatly benefited the Bell campaign as Constitutional Unionists exploited the relationship of their southern Democratic opponent, Breckenridge, with radical southerners such as like Yancey and Rhett.

Possibly the most damning political moment for the Breckenridge campaign was Crittenden's speech on behalf of Bell at Mozart Hall in Louisville on August 2, 1860. Crittenden

\footnotetext{
188 Joseph Patterson to Adah, June 29, 1860, Joseph Patterson Letter, KHS.

189 Ramage and Watkins, Kentucky Rising, 284.

190 Ibid.

${ }^{191}$ Klotter, A Concise History of Kentucky, 72.
} 
took to the podium and began by praising Bell and the Constitutional Union as "moderate, calm, and patriotic." ${ }^{192}$ He emphasized the party's attachment to the Union and its fight against sectionalism that threatened the Union, both the northern variety embodied by Republicans and the southern version embodied by southern Democrats. But the respected Kentucky statesman's scathing critique of Breckenridge served as the climax of the speech. Crittenden declared that, "There is not a disunionist South of the Mason-Dixon Line that does not support that party [Southern Democratic]....that does not support that candidate [Breckenridge]."193 Crittenden concluded that while Breckenridge himself may not be a disunionist, at least his associates were, and that represented danger enough to warrant the support of Bell.

These accusations from Crittenden and similar remarks from other Kentuckians represented a grave threat to the Breckenridge campaign. The potential for damage was so great that Breckenridge broke with antebellum political tradition and like Douglas took to the stump to speak in favor of his candidacy. The story wrote itself for the Journal which called the event a “disgraceful spectacle of a candidate for president on the stump." ${ }^{194}$ The fact that Breckenridge spoke out personally to combat charges of disunion demonstrates both the gravity of the accusations, and the fact that they worked. Breckenridge took to the stump at a barbeque near Ashland held by James B. Clay, the grandson of Henry Clay, on September 5, 1860. Assuredly, the location and host were designed to convey his respect for both Henry Clay and the Union. Breckenridge argued that southern Democrats supported the Constitution, the Union, and sought to protect Americans' constitutional right to bring their slaves property into U.S. territories. Breckenridge believed that the 1857 Dred Scott decision confirmed the constitutionality of his

\footnotetext{
192 John J. Crittenden, "The Union, the Constitution, and the Laws," August 2, 1860, FHS.

193 Ibid.

194 “Breckenridge and Disunion," Louisville Weekly Journal, September 12, 1860, 2.
} 
position and required Congress to protect slaveholders' property rights throughout the entire U.S. ${ }^{195}$ He professed to support the Constitution and the Union and challenged that "The man does not live in or out of the Commonwealth of Kentucky...who has power enough to connect my name with the slightest taint of disunion." 196 Despite his personal speech, Breckenridge could not escape the allegations of disunion running rampant among his associates and party.

The continued allegations offered by Kentucky Constitutional Unionists and their newspapers did not allow Breckenridge to escape the taint of disunion. On June 20, the Journal, in an article titled "The Conspiracy Against the Union," stated that "the Union is profoundly endangered by the Southern Democrats." ${ }^{197}$ On July 25, a public letter by Garrett Davis referred to Breckenridge supporters as "avowed disunionists." 198 On August 15, the paper announced that “The Breckenridge Party is to all intents and purposes a disunion party. It was got up by Disunionists for Disunion purposes and other disunionists are joining it from time to time for disunion purposes." ${ }^{\prime 99}$ On September 5, the paper ran a headline reading, "Breckenridge and Disunion." The same day, the paper acknowledged that Breckenridge may not be disunionist, but stressed that "almost the solid body of his supporters are."200 The attacks upon Breckenridge and his associates as disunionists continued unceasingly throughout the campaign.

A key tactic of Kentucky Constitutional Unionists was to associate Breckenridge with known disunionists such as William Lowndes Yancey rather than throw accusations at him directly. Indeed, the well-known fire-eaters had become every bit the villains that northern

\footnotetext{
195 John C. Breckenridge, Speech Near Ashland, September 5, 1860. FHS.

196 Ibid., 11.

197 "The Conspiracy against the Union," Louisville Weekly Journal, June 20, 1860.

198 "Letter of Hon. Garrett Davis," Louisville Weekly Journal, July 25, 1860.

199 "The Disunion Party-A direct avowal," Louisville Weekly Journal, August 15, 1860.

200 "Breckenridge and Disunion," Louisville Weekly Journal, September 5, 1860.
} 
abolitionists were to Kentuckians. Association rather than indirect attacks allowed Kentucky Constitutional Unionists to score political points while maintaining that they respected the Kentucky favorite. On August 8, a headline reading, "The Disunion Ticket” listed the name of Yancey for president alongside Breckenridge. ${ }^{201}$ On August 15, the Journal referred to the Democratic faction as "Yancey-Breckenridge-ism."202 Constitutional Unionists' contempt for Yancey shone brightest in the August 15 edition of the Journal which stated that "Mr. Yancey fancies himself 'looking down upon the friends of Bell and Everett.' He will never be able to look down on them unless they attend his hanging." ${ }^{203}$ The paper's efforts to associate Breckenridge with Yancey, a well-known and open disunionist, did irreparable damage to the Breckenridge campaign and led many Kentuckians into the Bell or Douglas camps.

Breckenridge supporters fully realized the danger the accusations of disunionism posed in Kentucky, and they tried to direct them back at their opponents. In an article entitled, "Beware of Disunion," the Courier accused Douglas of disunion on the grounds of his alleged subversion of the fugitive slave laws. ${ }^{204}$ On September 22, the Courier accused Bell and Everett supporters in Alabama of "rampant secessionism" and asserted that a Bell elector in Florida was an open disunionist. $^{205}$ James B. Clay, the grandson of Henry Clay, stumped for Breckenridge likely in an effort to associate him with the great unionist. ${ }^{206}$ Yancey even appeared at a speaking engagement at the Louisville Courthouse in order to soften the image of his faction of the party. Yancey stated that he hoped his speaking tour would benefit any candidate but Lincoln. He

\footnotetext{
201 "The Disunion Ticket," Louisville Weekly Journal, August 8, 1860.

202 "The South True to Union," Louisville Weekly Journal, August 15, 1860.

${ }^{203}$ Louisville Weekly Journal, August 15, 1860.

204 "Beware of Disunion," Louisville Weekly Courier, August 11, 1860.

205 "Disunion Bell-ites," Louisville Weekly Courier, September 22, 1860.

206 "James B. Clay," Louisville Weekly Courier, October 27, 1860.
} 
portrayed the Republicans as the greatest threat to slavery and the union, but could not resist a dig at Bell that his party, "says nothing....proposes nothing."207

The Breckenridge campaign efforts to convince voters of their Unionism fell short. It did not help that Breckenridge refused to answer questions regarding his statements about states' right to secession. During a campaign stop in Norfolk, Virginia, Douglas challenged Breckenridge to answer whether states had the right to secede and whether the government ought to use force to keep the Union together. ${ }^{208}$ It appears that Breckenridge refused to answer the secession question directly. In response the Courier turned the attack on the Constitutional Union campaign asking Bell to answer questions more directly. ${ }^{209}$ The Courier did Breckenridge no favors on September 22 when they ran an article titled, "The Right of Revolution," which criticized Douglas for denying the right of secession. ${ }^{210}$ The accusations, based on comments such as these, Breckenridge's association with avowed secession supporters like Yancey, and Breckenridge's past pronouncements on secession, tied Breckenridge to secession politics and damaged his reputation amongst many Kentucky voters.

The rhetoric of the Constitutional Union did not simply tie Breckenridge to disunion, but it also emphasized Bell's pro-Union credentials. The party's motto, taken from Henry Clay himself, celebrated, "The Union, the Constitution, and the Laws." 211 The campaign biography, distributed to voters, included a full copy of the United States Constitution. ${ }^{212}$ The party's banner depicted Bell and Everett holding a copy of the Constitution with the caption, "The Candidates

\footnotetext{
207 "Great Speech of William Lowndes Yancey," Louisville Weekly Courier, October 27, 1860.

${ }^{208}$ E.D. Fite, The Election of 1860, 186-7.

209 “The Norfolk Questions Again," Louisville Weekly Courier, September 22, 1860.

210 "The Right of Revolution," Louisville Courier, September 22, 1860.

${ }^{211}$ Fuller, The Election of 1860 Reconsidered, 106.

212 Constitutional Union Party, "The Life, Speeches, and Public Services of John Bell," 106.
} 
and their Platform." Across the top of this banner, a bald eagle held in its talons the message, "No North, no South, no East, no West, nothing but the Union." ${ }^{213}$ A handbill distributed to voters in Kentucky urged them to "Remember our state motto: United we stand divided we Fall." The same handbill reprinted George Washington's farewell address warning against partisan strife. ${ }^{214}$ The symbolism of the party's campaign messages tied Bell to the cause of national unity. Invoking Kentucky's state motto and the words of its famous statesman Clay, tied Bell and Kentucky to the quest for consensus and Union. The Journal hammered home Bell's pro-Union message, consistently referring to him as a patriot, a national candidate, and an ardent unionist.

The Constitutional Union Party's attacks on the disunionism of Breckenridge's southern Democrats had the desired effect. Kentuckians believed that the Union served as a positive good for both political culture and practical reasons, and they granted Bell, the most pro-Union candidate, the state's electoral votes. The rhetoric of Union and national reconciliation carried the day in Kentucky, as Bell defeated Breckenridge by over thirteen thousand votes. But Unionism in Kentucky was also tied to slavery. Therefore, the Constitutional Union message in 1860 also emphasized Bell's proslavery credentials.

\section{Slavery: The (Other) Primary Issue}

The issue of African slavery and the future of the institution in the United States lay at the heart of the 1860 election and the Civil War that followed. The four parties and candidates took different stances on the issue of slavery and its extension. Lincoln and the Republicans opposed the extension of slavery into both new and existing U.S. territories. Northern Democrats endorsed the principle of popular sovereignty as stated in Douglas's Freeport Doctrine.

\footnotetext{
213 Constitutional Union Party, “Grand National Union Banner," 1860.
}

214 Price, "The Storm of Disunion over a Border State," 1. 
Breckenridge Democrats embraced the Dred Scott decision of the Taney court and supported the congressional protection of slavery and its extension into all U.S. territories. The Constitutional Union platform did not enunciate a clear position on slavery and called instead for an end to the discussion of slavery at the national level as it only bred sectionalism and unnecessary conflict. In Kentucky, the Constitutional Union Party sought to assure voters that they were as capable as Breckenridge Democrats of protecting the institution of slavery.

The positions of Douglas and Lincoln on slavery effectively disqualified them from serious contention in Kentucky. Both the Breckenridge and Bell campaigns in Kentucky attacked Douglas's position on "squatter sovereignty" and decried Republicans as northern agitators at best and abolitionists at worst. On the subject of slavery in Kentucky in 1860, the contest became a fight for ground between the Breckenridge and Bell campaigns over who was more proslavery. The Breckenridge Democrats portrayed Bell as lukewarm on slavery pointing to his vote on Lecompton, his party's failure to take a strong proslavery stand, and his northern running mate Everett. Kentucky Constitutional Unionists answered these criticisms by emphasizing Bell's statements in the Senate on slavery, his status as a slaveholder, and his record as a prudent and reasonable defender of the peculiar institution. They also criticized Breckenridge, alleging that he had supported popular sovereignty or even anti-extension measures in the past. The 1860 election in Kentucky followed the pattern of antebellum southern elections described by historian William Cooper in The South and the Politics of Slavery. Both parties attempted to portray themselves as the better protectors of slavery. ${ }^{215}$

\footnotetext{
${ }^{215}$ William Cooper, The South and the Politics of Slavery, 1828-1856 (Baton Rouge, LA: Louisiana State University Press, 1978), XV. This may well cast some doubt on the general argument of Tallant that Kentuckians saw slavery as a necessary evil. As the election went on, it seems both parties' proslavery rhetoric greatly heated up.
} 
Though Crittenden, the party's most prominent Kentuckian, may have viewed slavery as "a great evil" and supported colonization efforts, the rhetoric of the Constitutional Union Party in Kentucky took a distinctly proslavery bent as the election approached. ${ }^{216}$ The proslavery rhetoric began mildly enough. On June 6, the Journal stated that Bell would support "the legal rights of the South." ${ }^{217}$ On July 25, they printed a letter from Garrett Davis, criticizing Douglas for promoting "squatter sovereignty" in the free states. ${ }^{218}$ In a printed reply to an Alabama constituent, Bell declined to enunciate a specific position on the extension of slavery, stating that the correspondent ought to "examine his public record." ${ }^{219}$ Bell's answer emphasized his moderate national course while remaining a reliable protector of slavery where it existed and in new regions where he believed it could expand. The national party in their letter "To the People of the United States" accurately characterized Bell and the party's position on slavery, noting that the expansion question would be settled by climate and soil of the territory. ${ }^{220}$

However, such mild statements endorsing southern legal rights proved inadequate, and the Journal soon began to portray Bell as a politician who favored slavery's extension and viewed the institution as a "positive good." In response to attacks from the Courier, the Journal stated that "John Bell, in both the House of Representatives and the Senate...defended the institution of slavery in all its moral, social, and political aspects. ${ }^{221}$ On August 22, they printed two full columns on Bell's proslavery record, presenting him as a politician who believed slavery

\footnotetext{
${ }^{216}$ Kirwan, John J. Crittenden, 344.

217 Louisville Weekly Journal, June 6, 1860.

218 "Letter of Hon. Garrett Davis," Louisville Weekly Journal, July 25, 1860.

219 “Letter from John Bell," Louisville Weekly Journal, August 8, 1860.

220 "To the People of the United States," Louisville Weekly Journal, August 15, 1860.

${ }^{221}$ Louisville Weekly Journal, August 15, 1860.
} 
a moral and economic positive for the nation. After stating that Africans come as "savages" on the Senate floor, Bell stated,

What do we now behold? These few thousand slaves have become a great people, numbering three millions, civilized, Christianized, with each generation developing some improved feature, -- Physical and Mental indicating much further approximation now to the race of their masters...I doubt whether the power and resources of the country would have attained more than one half of their present, extraordinary proportions but for the so much reviled institution of African slavery. ${ }^{222}$

On the constitutionality of the extension of slavery to the territories, the paper also included a lengthy quotation by Bell:

The Constitution, in its application to this territory [Kansas] is expected not merely to protect property in slaves as is the case in Oregon, before there was any exercise of sovereignty upon the subject, but to supersede local laws prohibiting slavery when the United States came into possession of it. ${ }^{223}$

Another lengthy defense of Bell's record on slavery came on September 22:

Of all the empty objections raised against John Bell in the South, the objection that he is unsound on the slavery question is the most absurdly empty...John Bell is the only candidate who as always voted directly against the Wilmot Proviso and squatter sovereignty. John Bell is the only candidate who has voted in favor of protection. John

222 "John Bell on African Slavery," Louisville Weekly Journal, August 29, 1860.

223 "Territorial Rights of the South," Louisville Weekly Journal, August 22, 1860. 
Bell is the only candidate who has declared that humanity to the slave no less justice to the master, requires the diffusion and expansion of slavery. ${ }^{224}$

The paper also praised Bell for voting in favor of an amendment that protected slavery in territories gained during the Mexican-American War. ${ }^{225}$

In addition, the Journal highlighted Bell's personal status as a slave owner and directed criticism at Breckenridge. "The Charges of abolitionism against Bell and Everett are almost universally made by men who own no niggers and who are quite as little fit to own niggers as they are to be owned by them." 226 Contrasting Bell's ownership of slaves to Breckenridge's was intended to send a clear message that Bell was more reliable on the subject of slavery than Breckenridge. The Journal clearly engaged in what Cooper calls the politics of slavery: "Let a man recognize distinctly that John Bell is as in favor of intervention as unequivocally as John C. Breckenridge." ${ }^{227}$ The same day, the paper claimed that abolitionist Cassius Clay supported Breckenridge as he purportedly did not own slaves. ${ }^{228}$ Constitutional Unionists in Kentucky likewise criticized Breckenridge for his alleged support of popular sovereignty during the 1856 presidential campaign and even claimed that he supported the Wilmot Proviso in 1848. ${ }^{229}$

The Breckenridge faction of the Democratic Party had the strongest proslavery platform in 1860, and it refused to cede ground to Constitutional Unionists. Breckenridge Democrats

\footnotetext{
224 Louisville Weekly Journal, September 12, 1860.

225 Ibid.

${ }^{226}$ Louisville Weekly Journal, September 19, 1860.

227 Louisville Weekly Journal, September 19, 1860. Cooper, The South and the Politics of Slavery, XV.

${ }^{228}$ Louisville Weekly Journal, September 19, 1860. It should be noted that while the Journal claimed Breckenridge did not own slaves, others have cited his ownership of purely domestic slaves. It may well be the case that the Constitutional Union accused Breckenridge of owning no slaves due to his failure to utilize them economically in agriculture or mining. It could also be the case of deliberate misrepresentation.

${ }^{229}$ John C. Breckenridge, Speech at Ashland, September 5, 1860. Yes, citation is correct. We know these accusations were made against Breckenridge because he referenced and addressed them in his speech
} 
regularly attacked the Constitutional Union and Bell as weak on slavery. The Courier referred to Bell and his "northern supporters" as abolitionists. ${ }^{230}$ Similarly, they tried to connect Bell to the Republican nomination at the Chicago convention. ${ }^{231}$ They called into question Bell's 1850 s voting record on slavery, citing his vote against the Kansas-Nebraska Act as well as the Lecompton Constitution. ${ }^{232}$ The Journal responded that while Bell voted against the proslavery constitution for Kansas, he did vote for the amendment proposed by Crittenden to admit Kansas as a slave state if a majority voted for slavery in a fair election. ${ }^{233}$ For Breckenridge Democrats, attacking Everett, a Massachusetts politician and obviously not proslavery in the southern sense, also served as a viable strategy. The criticism arose so early and often that it forced Everett to respond publicly in a letter to accusations he harbored antislavery views. Everett reiterated his support for the 1850 compromise, and stated that his views on slavery accorded with those of Henry Clay. ${ }^{234}$

On the slavery question, the Constitutional Union left its platform intentionally vague. The party did not try to be all things to all people, but rather its leaders believed that the slavery debate had gone too far. If it continued, they feared the Union would split along sectional lines. Ultimately, Bell was a conservative pragmatist who remained committed to slavery's protection. He supported the institution of slavery in areas where it already existed, and he believed that the extension of slavery depended solely on whether the soil and climate of a territory could support the institution. He did not believe Kansas or Nebraska could support slavery, so he declined to support its extension there because it served only to agitate northerners and threaten the Union.

\footnotetext{
230“Vote for McClarty," Louisville Weekly Courier, August 4, 1860.

231 "Black Republican Sentiments," Louisville Weekly Courier, September 22, 1860.

232 "Mr. Bell's Record," Louisville Weekly Courier, September 22, 1860.

233 Louisville Weekly Journal, August 15, 1860.

234 “Mr. Everett's Position," Louisville Weekly Journal, July 25, 1860.
} 
Bell thought that slaveholders ought to pick their battles and, for their own good and the good of the Union, not overreach. He concluded that agitation over slavery served only to endanger the peculiar institution. $^{235}$

Many white Kentuckians appreciated Bell's moderation on and support for slavery. His votes against Kansas-Nebraska and the Lecompton Constitution demonstrated his willingness to place the national interest ahead of sectional concerns. However, his status as a slave owner and his votes for the protection and, under the right circumstances, extension of slavery assured them that he would also safeguard the institution in Kentucky. The heightened rhetoric concerning slavery during the 1860 election demonstrated Kentuckians' firm attachment to the institution where it existed and their openness to its expansion. The fight over the high ground on proslavery issues raises serious questions about whether white Kentuckians saw slavery as a necessary evil. The slavery debate in 1860 revealed that they sought a candidate who was sufficiently proslavery. Constitutional Unionists succeeded in convincing Kentuckians that Bell could be trusted to protect the peculiar institution in the state. As the candidate best able to protect the Union and sound on the issue of slavery, Bell overcame Breckenridge and carried the state of Kentucky in 1860.

\section{The Fight over Henry Clay's Legacy}

The 1860 campaign also revealed the importance of Henry Clay's persisting importance in Kentucky politics. Bell and Breckenridge supporters argued over whose candidate best served as the inheritor of Clay's legacy. The Breckenridge campaign stirred up a controversy, hoping that he might claim the mantle of Clay and thereby pull away some old Whig voters from Bell.

235 Parks, John Bell, 328. 
Early in the campaign, Constitutional Unionists staked their claim to Clay's legacy. On June 27, the Journal urged Kentuckians to uphold the mantra of Clay, "The Union, the Constitution, and the Laws," by supporting the Bell-Everett ticket. ${ }^{236}$ Most former Whig politicians and their supporters joined the Constitutional Union Party to save the union from sectional conflict, the primary goal of Clay's political career. However, Clay's political inheritance was more complicated than it seemed at first. In the 1848 election, after Crittenden failed to endorse Clay's nomination bid, the two statesmen had a falling out and Kentucky Whigs split into two factions. ${ }^{237}$ Crittenden tried to heal the division, but Clay's hard feelings persisted, and the Clay faction denied Crittenden a Senate seat in the early 1850 s, instead supporting Archibald Dixon. ${ }^{238}$ The divide left a mark on Kentucky Whiggery and Crittenden's career. Bell too had not always supported Clay's politics. He believed, for example, that while Congress had the power and ought to distribute funds for internal improvements, it could not oversee the actual projects as Clay proposed. $^{239}$

Breckenridge Democrats attempted to drive a wedge between Bell and Clay’s legacy by drudging up the "corrupt bargain" when a young Bell had still been a Jacksonian. In the 1824 election, a four-way contest between Andrew Jackson, Clay, John Quincy Adams, and William Crawford, no candidate received a majority in the electoral college, forcing the House to decide between Jackson, Adams, and Clay. As speaker of the House, Clay threw his support behind Adams, despite the fact that Jackson had won the popular vote, and Adams won the election.

\footnotetext{
236 “The Campaign Opened," Louisville Weekly Journal, June 27, 1860.

${ }^{237}$ Kirwan, John J. Crittenden, 274-5.

238 Ibid.

${ }^{239}$ Fuller, The Election of 1860 Reconsidered, 108-9.
} 
Once president, Adams named Clay his Secretary of State, and allegations abounded that Clay supported Adams and denied the will of the people, in exchange for the cabinet position.

Breckenridge Democrats revived this thirty-six-year old controversy in order to tarnish Bell and claim the mantle of Clay. On August 6, the Courier, stated that in 1824 Bell had questioned Clay's honor and added his name to the list of individuals who decried the corrupt bargain. ${ }^{240}$ They believed that Bell had unjustly attacked Clay, "whose memory is dear to all Kentuckians," and made himself undeserving of the Great Compromiser's legacy. ${ }^{241}$ In a speech at Bardstown, James B. Clay, grandson of Henry Clay, made similar accusations against Bell. ${ }^{242}$ The Journal retorted that the events discussed had transpired over thirty years prior, while Bell was still a Jacksonian. The two men worked together within the same party for thirty years, and "nobody ever heard Henry Clay speak of John Bell except in terms of high respect and regard." 243 Nonetheless, the Democrats continued to push the issue and used Clay's grandson on the stump in a bid for the Great Compromiser's legacy. The Journal responded with columns such as "Henry Clay’s Opinion of John Bell," which described an instance in which Clay praised Bell for "firmness and integrity." 244

At the polls, Breckenridge Democrats' bid for Clay's mantle fell short. Bell's electoral success in Kentucky Whig strongholds that had also supported Clay demonstrated that voters viewed Bell's message of union, moderation, and compromise as part of Clay's political legacy. As a result, Bell retained the Whig electoral base required to win in the commonwealth.

\footnotetext{
240 “Bargain, Intrigue, and Corruption," Louisville Weekly Courier, August 4, 1860.

241 Ibid.

242 Louisville Weekly Journal, August 8, 1860.

243 Ibid.

244 “Henry Clay's Opinion of John Bell," Louisville Weekly Journal, October 10, 1860.
} 


\section{Chapter III: Analysis of the Results and Border State Comparison}

\section{$\underline{\text { Results in Kentucky }}$}

John Bell carried the state with 66,058 votes and 45.18 percent of the statewide count.

Breckenridge ran second with 53,143 votes and 36.35 percent of the vote, while Douglas ran third with 25,638 votes and 17.5 percent of the vote. ${ }^{245}$ Lincoln received less than 1 percent of the statewide count amounting to 1,364 votes. ${ }^{246}$ In the election of 1860,67 percent of eligible white male Kentuckians voted, less than a point below the nationwide average. ${ }^{247}$ The statewide electoral count illuminates the influence of partisan loyalty and past voting behavior, Douglas's denial of votes to Breckenridge in key counties, and the success of the Constitutional Union's proslavery message in gaining the support of voters in large slaveholding regions.

The continuity of voting along Whig and Democratic Party lines becomes evident in the county-by-county vote totals. Most traditional Whig strongholds gave Bell a majority of their vote. For example, the largest Whig strongholds such as Jefferson County (Louisville) gave Bell 4,896 votes to Breckenridge's 1,122 and Douglas's 3,341. Fayette County (Lexington, inner Bluegrass) behaved in a similar manner with Bell receiving 1,411 votes to Breckenridge's 1,051 and Douglas's 99. ${ }^{248}$ Bell won a majority in five other counties in Kentucky's inner Bluegrass, including the traditional Whig strongholds of Bourbon, Clark, Jessamine, Woodford, and Madison Counties. ${ }^{249}$ Similarly, Bell carried Owensboro and Henderson, both traditional Whig

\footnotetext{
245 "1860 Presidential Election Results: Kentucky," http://uselectionatlas.org/RESULTS/state.php?f=0\&fips=21\&year=1860 accessed 2/10/2015. 246 Ibid.

247 Williams and Harris, "Kentucky in 1860: A Statistical Overview," 759.

248 Ibid., 747-8.

249 lbid., 748.
} 
bastions. ${ }^{250}$ This demonstrates an obvious correlation between Whig and Constitutional Union voters despite the collapse of the Whig Party six years earlier. The continuity of Whig identity and partisan support helps explain Bell's plurality. However, Bell did not carry all traditional Whig strongholds as Breckenridge enjoyed a majority of the Franklin County (Frankfort) vote. ${ }^{251}$ As Bell generally ran well in formerly Whig counties, so too did Breckenridge run well in traditional Democratic areas. Breckenridge carried majorities in many counties in the Jackson Purchase, the far western region of the state, and the Appalachian region in the far east, both traditional areas of Democratic power. ${ }^{252}$

In addition to his success in former Whig strongholds, Bell's plurality resulted partially from Democratic votes Douglas denied Breckenridge in key areas. Without the Democratic votes garnered by Douglas, Bell may well have been defeated by Breckenridge. Douglas took a large number of votes from Breckenridge in counties as far west as Warren County (Bowling Green) where he earned 615 to Breckenridge's $182 .{ }^{253}$ Douglas even carried Larue County in the eastern Pennyroyal region (central Kentucky), earning 450 votes while Breckenridge took only $32 .{ }^{254}$ Douglas ran strongest in the Marion, Washington, Taylor, Nelson, and Hart County area carrying all of these traditionally Democratic areas and denying them to Breckenridge. ${ }^{255}$ A large chunk of Douglas votes inhibited Breckenridge from gaining a key slice of the urban vote in Louisville and northern Kentucky. Douglas earned 2,500 votes in northern Kentucky across the river from Cincinnati (Boone, Campbell, Kenton Counties), carrying Kenton, and 3,341 from Louisville..$^{256}$

\footnotetext{
250 Ibid., 760.

251 Ibid., 747.

252 Ibid., 761.

253 Ibid., 745.

254 Ibid., 746.

255 Ibid., 762.

${ }^{256}$ Ibid., 747-8.
} 
The twenty five thousand votes earned by Douglas represented a split in the Democratic Party and opened the door for Bell to win Kentucky with a plurality of votes.

In general, Breckenridge, the most proslavery candidate, did not run well in counties with the largest amount of slaves. What does this reveal about the rhetoric of the campaign? It seems to substantiate the fact that the Constitutional Union's proslavery message in Kentucky worked, at least enough to convince many slaveholders that their property was safe under a Bell administration. Henderson County, in the western part of the state, had a population of 712 slave owners and 5,767 slaves. Bell received nearly four hundred more votes than Breckenridge. Logan County, in the western Pennyroyal region, featured over six thousand slaves and one thousand slaveholders, and Bell defeated Breckenridge by over 1,000 votes. Similarly, in Barren County in the eastern Pennyroyal region, with 689 slave owners and 4,078 slaves, Bell received roughly eight hundred more votes than Breckenridge. The inner Bluegrass region, around Lexington, featured the largest and most established plantations in the state along with the state's largest slave market. The seven counties in the inner Bluegrass region, held 42,849 slaves and 5,764 slaveholders. Bell carried six of the seven and received over 1,000 more votes than Breckenridge. ${ }^{257}$ While Bell achieved electoral success in large slaveholding areas, Breckenridge carried the region where the institution was growing fastest within the commonwealth, the farwestern Jackson Purchase area. ${ }^{258}$ However, when the dust settled, Breckenridge carried only one (Scott County) of the Commonwealth's twenty largest slave counties, and Bell carried seventeen. Similarly, Breckenridge managed to carry just three of the top twenty counties in terms of number of slaveholders. ${ }^{259}$

\footnotetext{
257 Ibid. 745-8.

258 Ibid. 745.

259 Ibid. 761-2.
} 
Bell's electoral success in regions with large numbers of slaves and slave owners seems to indicate that many Kentuckians with the strongest attachment to the peculiar institution believed that Bell and the Constitutional Union would protect the institution of slavery. Many Kentuckians attached this desire to protect the institution of slavery to the Union, believing that peace and stability afforded by the Union would protect slavery in Kentucky. This duality of slavery and Union in Kentucky politics gave Bell and the Constitutional Union Party the proper rhetorical foundation needed to woo Kentucky voters. Bell offered white Kentuckians a chance to maintain the Union and the institution of slavery. Rather than seeing these interests as contradictory, a plurality of Kentuckians saw them as complementary and the Constitutional Union Party as the best source for their security.

Bell benefited from the support of many former Whigs and the continuing strength of the Whig Party legacy in Kentucky. Former Whig strongholds provided Bell with his most reliable base of support. The division of the Democratic Party and the roughly twenty-five thousand votes earned by Douglas served to open the door and tip the scales in favor of a Bell victory in Kentucky. The Constitutional Union campaign message of strong pro-Union values, the accusations of disunion against Breckenridge, and the ability of Kentucky Constitutional Unionists to portray Bell as ready and able to protect the institution of slavery sealed his victory. The party's message reflected the attitudes of Kentucky voters and ensured Breckenridge's defeat. Bell gained a large plurality of Kentucky’s vote, over 45 percent, and garnered the commonwealth's twelve electoral votes.

\section{Border State Comparison: Virginia}

Overall, John Bell won only thirty-nine electoral votes, adding fifteen from Virginia and twelve from his native Tennessee to the twelve from Kentucky. He also ran well in Maryland, Missouri, 
and North Carolina. These results demonstrate the success of the Constitutional Union Party's message in the Upper/Border South during the 1860 election. A brief overview of Bell's campaign in another Border State, Virginia, reveals that the factors that enabled Bell to win in Kentucky shaped his success across the Upper/Border South. In 1860, Bell narrowly carried Virginia with 74,481 votes (44.63 percent) to Breckenridge's 74,325 (44.54 percent,) and Douglas's 16,198 (9.71 percent), Lincoln’s 1,887 (1.13 percent). ${ }^{260}$

Bell's victory in Kentucky depended on the support of former Whig voters clustered in specific geographic regions and prominent former Whig politicians from the state. The collapse of the Whig Party sent its Kentucky supporters to the American Party and then to the “Opposition.”. In Virginia, this same movement of voters can be observed. In the Old Dominion, Bell ran best in former urban Whig strongholds such as Richmond and Norfolk and the slaveholding Tidewater. ${ }^{261}$ This mirrored Bell's success in the urban areas of Louisville and Lexington and the established slaveholding inner Bluegrass Region. The same general Whig to Know-Nothing to Opposition to Constitutional Union transition took place in Virginia as the American Party dominated urban Whig areas of Richmond and Norfolk in the mid-1850s. ${ }^{262}$ After the collapse of the American Party, the Opposition arose to fill the void in Whig strongholds in $1859 .{ }^{263}$ As in Kentucky, former Whig politicians such as John Minor Botts, William Goggins, and William Cabell Rives led the Constitutional Union effort. ${ }^{264}$ The endorsement and support of these Whig veterans in Virginia lent credibility to the campaign, as in Kentucky.

\footnotetext{
260 “1860 Presidential General Election Results: Virginia,” http://uselectionatlas.org/RESULTS/ accessed 2/05/2015.

261 Link, Roots of Secession, 208.

262 Ibid. 87, 122-3.

263 Ibid. 170-1.

264 Ibid. 200-2.
} 
The split in the Democratic Party and the defection of some state Democratic voters from Breckenridge to Douglas provided the second ingredient for Bell's victory in Kentucky. Douglas peeled away key votes from Breckenridge's Democratic base, especially in urban areas such as Louisville and northern Kentucky. In Virginia, Douglas polled roughly sixteen thousand votes. If any significant number of these had gone for Breckenridge, Bell's one hundred and fifty vote victory in Virginia would have dissolved. The defection to Douglas of many voters in the city of Richmond and towns in the northwest of the state enabled the Constitutional Union to carry Virginia in $1860 .{ }^{265}$ As in Kentucky, a Democratic vote divided between Breckenridge and Douglas opened the door for a Bell victory.

In order to secure victory and gain the support of Kentucky voters, the Constitutional Union's campaign focused on a pro-Union message along with assurances that the party would protect the institution of slavery at least as well as Breckenridge Democrats. The Virginia Constitutional Union Party broadcasted a similar message. In 1859, the Opposition (later Constitutional Unionist) platform stated that the "safest guarantee of liberty of the people and the safest support of their peace and prosperity" was the Union. ${ }^{266}$ The Virginia Constitutional Union Party delegates to the national convention pledged to support no limitations on the institution of slavery. ${ }^{267}$ As in Kentucky, Virginia Democrats attempted to label the Constitutional Union Party antislavery, while Constitutional Union papers like the Richmond Whig advocated their support of the institution. The Whig went so far as to advocate the re-opening of the African slave trade. ${ }^{268}$ When the ballots were cast, the pro-Union and proslavery rhetoric worked. As in

\footnotetext{
265 Ibid., 208.

266 Ibid., 171.

267 Ibid., 197.

268 Ibid. 160-1.
} 
Kentucky, the "Union loving conservative people of the good old commonwealth had triumphed." 269

An analysis of the 1860 election demonstrates that the Constitutional Union Party followed a similar path to success in both Kentucky and Virginia and likely throughout the Upper South where they gained substantial support. In both Kentucky and Virginia, the Constitutional Union organized a base among former Whig voters, benefited from Douglas

Democratic votes, and employed proslavery and pro-Union rhetoric to sway a plurality of voters.

These ingredients brought electoral victory to John Bell and the Constitutional Union in Kentucky in the presidential election of 1860.

$\underline{\text { Regional Breakdown: }{ }^{270}}$

\begin{tabular}{|l|l|l|l|l|}
\hline Kentucky Region & Bell & Breckenridge & Douglas & Lincoln \\
\hline Jackson Purchase & 2,885 & $\mathbf{4 , 5 4 7}$ & 1,089 & 10 \\
\hline Western Coalfield & $\mathbf{6 , 5 6 1}$ & 4,174 & 3,453 & 36 \\
\hline Western Pennyroyal & $\mathbf{8 , 8 0 8}$ & 4,392 & 2,927 & 35 \\
\hline Eastern Pennyroyal & $\mathbf{9 , 0 0 7}$ & 4,613 & 5,148 & 113 \\
\hline Southern Bluegrass & $\mathbf{4 , 1 8 0}$ & 2,802 & 2,648 & 31 \\
\hline Greater Louisville & $\mathbf{7 , 2 2 9}$ & 2,205 & 4,677 & 110 \\
\hline Inner Bluegrass (Lex) & $\mathbf{6 , 3 4 4}$ & 5,393 & 341 & 97 \\
\hline Northern Kentucky & $\mathbf{4 , 8 8 0}$ & 3,845 & 2,877 & 584 \\
/Greater Cincinnati & & & & 33 \\
\hline Eastern Bluegrass & $\mathbf{5 , 9 7 7}$ & 5,897 & 909 & \\
\hline
\end{tabular}

269 Ibid., 209.

270 Williams and Harris, "Kentucky in 1860: A statistical overview," 745-50. 


\begin{tabular}{|l|l|l|l|l|}
\hline Northeast Appalachia & 3,298 & $\mathbf{4 , 6 0 3}$ & 490 & 54 \\
\hline Southeast Appalachia & 3,891 & $\mathbf{5 , 1 5 9}$ & 262 & 258 \\
\hline
\end{tabular}

Table 2 Kentucky Election Results: 271

\begin{tabular}{|l|l|l|}
\hline Candidate & Popular Vote & Percentage \\
\hline Bell & 66,058 & 45.18 \\
\hline Breckenridge & 53,143 & 36.35 \\
\hline Douglas & 25,651 & 17.54 \\
\hline Lincoln & 1,364 & 0.93 \\
\hline
\end{tabular}

271 "1860 Presidential General Election Results: Kentucky,"

http://uselectionatlas.org/RESULTS/state.php?f=0\&fips=21\&year=1860, accessed 2/05/2015 


\section{Primary Sources:}

Bodley Family Papers. July to September, 1860. MSS A B668e. Boxes 64, 65. Filson Historical Society, Louisville, Kentucky.

Boyd, Wherritt, and Wilson Family Papers. April to October, 1860. Kentucky Historical Society, Frankfort, Kentucky.

Breckenridge, John C. “Speech of John C. Breckenridge at Ashland near Lexington.” September 5, 1860. Kentucky Historical Society, Frankfort, Kentucky.

Brutus Clay Papers. Clay Family Papers, Box 12. Margaret I. King Library, University of Kentucky.

Cassius Clay Papers. MSS CS. November 15, 1857. Filson Historical Society, Louisville, Kentucky.

Constitutional Union Party, Massachusetts, Leverett Saltonstall to Hon. John F. Henry. September 7, 1860. MSS CS. Filson Historical Society, Louisville, Kentucky.

Constitutional Union Party. “The Life, Speeches, and Public Services of John Bell.” 1860. Library of Congress.

Crittenden, John C. "The Union, the Constitution, and the Laws: Speech at Mozart Hall, Louisville, Kentucky.” August 2, 1860. Filson Historical Society, Louisville, Kentucky.

Constitutional Union Party. “Grand National Union Banner.” 1860. Library of Congress.

Duncan Family Papers. Margaret I. King Library, University of Kentucky.

Frost Family Papers. MSS CF. July 2, 1860. Filson Historical Society, Louisville, Kentucky.

Haycraft, Samuel Jr. Diary. MSS A H 414 86x16. March to May 1861. Filson Historical Society, Louisville, Kentucky.

John J. Crittenden Papers. Leslie Combs to John J. Crittenden, March 15, 1859. Margaret I. King Library, University of Kentucky.

Joseph Patterson Letter. June 29, 1860. Kentucky Historical Society, Frankfort, Kentucky.

Louisville Weekly Courier. 1860. Ekstrom Library, University of Louisville. Microfilm.

Louisville Weekly Journal. 1860. Ekstrom Library, University of Louisville. Microfilm.

Marshall Family Papers. July 8, 1860. MSS A M367. Filson Historical Society, Louisville, Kentucky.

National Committee of the Constitutional Union Party. “To the People of the United States.” 1860. Library of Congress. 
"The Presidential Controversy. The True Policy for the South. Letters of Messrs. Taylor, Bouligny, Fonce, and Hamilton on the Political Questions of the Day.” January 19, 1860. Kentucky Historical Society.

Scott, Joseph F. July 8, 1860. MSS CS. Filson Historical Society, Louisville, Kentucky.

\section{Secondary Sources:}

Ashworth, John. Slavery, Capitalism and Politics in the Antebellum Republic: The Coming of the Civil War, Volume II. Cambridge, United Kingdom: Cambridge University Press, 2007.

Crenshaw, Ollinger. The Slave States in the Presidential Election of 1860. Gloucester, MA: Johns Hopkins Press, 1969.

Cooper, William. The Politics of Slavery. Baton Rouge, LA: Louisiana State University Press, 1978.

Cole, Arthur Charles. The Whig Party in the South. Gloucester, MA: The American Historical Association, 1962.

Coleman, J. Winston. Slavery Times in Kentucky. Chapel Hill, NC: University Press of North Carolina, 1940.

Egerton, Douglas R. Year of Meteors: Stephen Douglas, Abraham Lincoln, and the Election that Brought on the Civil War. New York, NY: New York Bloomsbury Press, 2010.

Fite, E.D. The Presidential Campaign of 1860. New York, NY: The Macmillan Company, 1960.

Foner, Eric. Free Soil, Free Labor, Free Men. New York, NY: The Oxford University Press, 1970.

Fuller, A. James. The Election of 1860 Reconsidered. Kent, OH: The Kent State University Press, 2013.

Halstead, Murat. Three Against Lincoln: The Caucuses of 1860. Baton Rouge, LA: Louisiana State University Press, 1960.

Harris, James Russell and Williams, Kenneth H. "Kentucky in 1860: A Statistical Overview," The Register of the Kentucky Historical Society 103 (2005): 743-764.

Harrison, Lowell. The Antislavery Movement in Kentucky. Lexington, KY: University of Kentucky Press, 1978.

Holt, Michael F. The Rise and Fall of the American Whig Party: Jacksonian Politics and the Onset of the Civil War. New York: Oxford University Press, 1999.

Jewett, Clayton E. and Allen, John O. Slavery in the South: A State by State History. Westport, CT: Greenwood Press, 2004. 
Johannsan, Robert W. "Stephen A. Douglas and the South.” The Journal of Southern History 33 (Feb. 1967): 26-50.

Kirwan, Albert D. John J. Crittenden and the Struggle for Union. Lexington, KY: University Press of Kentucky, 1962.

Klotter, James C. and Klotter, Freda C. A Concise History of Kentucky. Lexington, KY: The University Press of Kentucky, 2008.

Link, William A. Roots of Secession: Slavery and Politics in Antebellum Virginia. Chapel Hill, NC: University of North Carolina Press, 2003.

Lucas, Marion. A History of Blacks in Kentucky: From Slavery to Segregation 1790-1891. Frankfort, KY: Kentucky Historical Society, 1992.

Mering, John V. "The Slave-State Constitutional Unionists and the Politics of Consensus.” The Journal of Southern History 43 (1977): 395-410.

Nevins, Allen. The Emergence of Lincoln. Volume II. New York, NY: Charles Scribner's Sons, 1950.

Paine, Christopher M. "Kentucky will be the Last to Give up the Union: Kentucky Politics: 1844 -1861.” Ph.D. Dissertation, University of Kentucky, 1998.

Parks, Howard Joseph. John Bell of Tennessee. Baton Rouge, LA: Louisiana State University Press, 1950.

Peters, Gerhard and Wooley, John. “Constitutional Union Party Platform.” Accessed 1/25/2015. http://www.presidency.ucsb.edu/ws/?pid=29571

Price, Charles B. Jr. “The Storm of Disunion over a Border State.” MA Thesis, Yale University, 1941.

Ramage, James and Watkins, Andrea S. Kentucky Rising. Lexington, KY: The University Press of Kentucky, 2011.

Tallant, Harold D. Evil Necessity: Slavery and Political Culture in Antebellum Kentucky. Lexington, KY: The University Press of Kentucky, 2003.

“1852 Presidential Election.” Accessed 1/20/2015. http://www.270towin.com/1852 Election/.

“1856 Presidential Election.” Accessed 1/26/2015. http://www.270towin.com/1856 Election/.

“1856 Presidential General Election Results: Kentucky.” Accessed 1/28/2015. http://uselectionatlas.org/RESULTS/state.php?fips $=21 \&$ year $=1856 \& \mathrm{f}=0 \&$ off $=0$

“1860 Presidential General Election Results: Kentucky.” Accessed 1/27/2015. http://uselectionatlas.org/RESULTS/state.php?fips $=21 \&$ year $=1860 \& \mathrm{f}=0 \&$ off $=0$. 
